Prepared in cooperation with the National Park Service, Western Arctic National Parklands, National Park Service, Kotzebue, Alaska

\title{
Assessment of Metals Exposure and Sub-Lethal Effects in Voles and Small Birds Captured Near the DeLong Mountain Regional Transportation System Road, Cape Krusenstern National Monument, Alaska, 2006
}

Scientific Investigations Report $2008-5211$ 
Front cover. View from haul road at New Heart Creek bridge looking northeast with sample preparation tent in background, Cape Krusenstern National Monument, Alaska, June 24, 2006. (Photograph taken by William Brumbaugh, U.S. Geological Survey). 


\section{Assessment of Metals Exposure and Sub- Lethal Effects in Voles and Small Birds Captured Near the DeLong Mountain Regional Transportation System Road, Cape Krusenstern National Monument, Alaska, 2006}

By William G. Brumbaugh, Miguel A. Mora, and Thomas W. May

Prepared in cooperation with the National Park Service, Western Arctic National

Parklands, National Park Service, Kotzebue, Alaska

Scientific Investigations Report 2008-5211 


\section{U.S. Department of the Interior DIRK KEMPTHORNE, Secretary}

\section{U.S. Geological Survey \\ Mark D. Myers, Director}

\section{U.S. Geological Survey, Reston, Virginia: 2008}

For product and ordering information:

World Wide Web: http://www.usgs.gov/pubprod

Telephone: 1-888-ASK-USGS

For more information on the USGS--the Federal source for science about the Earth, its natural and living resources, natural hazards, and the environment:

World Wide Web: http://www.usgs.gov

Telephone: 1-888-ASK-USGS

Any use of trade, product, or firm names is for descriptive purposes only and does not imply endorsement by the U.S. Government.

Although this report is in the public domain, permission must be secured from the individual copyright owners to reproduce any copyrighted materials contained within this report.

Suggested citation:

Brumbaugh, W.G., Mora, M.A., and May, T.W., 2008, Assessment of metals exposure and sub-lethal effects in voles and small birds captured near the DeLong Mountain Regional Transportation System Road, Cape Krusenstern National Monument, Alaska, 2006, U.S. Geological Survey Scientific Investigations Report 2008-5211, 22 p. 


\section{Contents}

Abstract

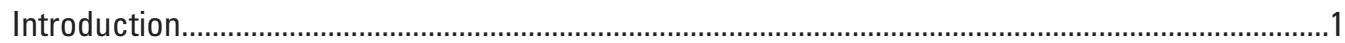

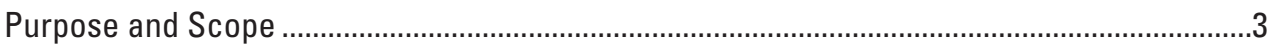

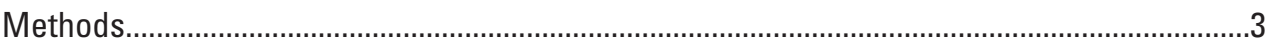

Sampling Design and Field Procedures .............................................................................

Laboratory Procedures for Determination of Metals .......................................................

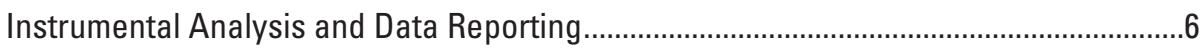

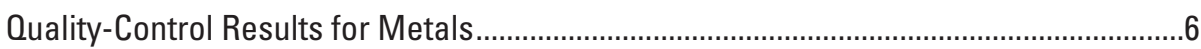

Tissue and Blood Examination Procedures........................................................................

Specimens Collected and Statistical Analysis ................................................................

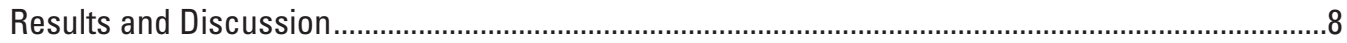

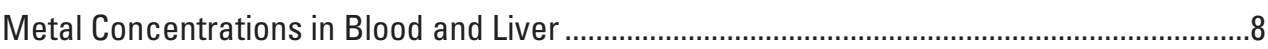

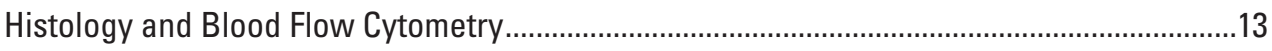

Comparison of Lead Concentrations to Other Studies ...........................................................13

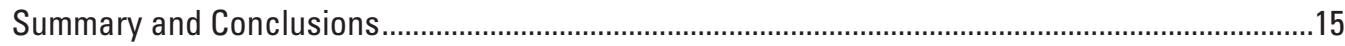

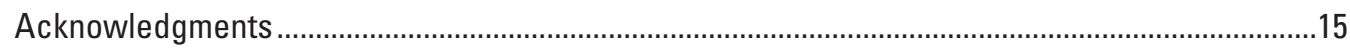

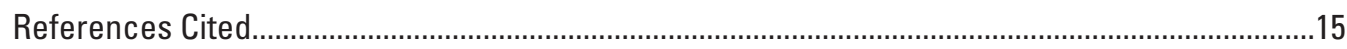

Appendix A. Quality-control results for metals in standard reference materials ..........................20

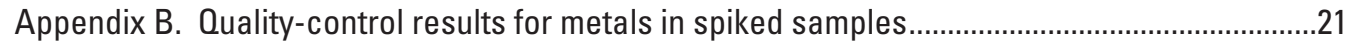

Appendix C. Quality-control results for metals in replicated samples ............................................22

\section{Figures}

1. Map showing sampling locations for voles and small birds captured in Cape Krusenstern National Monument, Alaska 2006

2-3. Graphs showing:

2. Comparison between blood and liver lead concentrations in voles and small birds captured near the DeLong Mountain Regional Transportation System road to those from a reference location. Error bars are plus or minus one standard error.

3. Blood and liver lead concentration in voles and small birds plotted according to capture distance from the DeLong Mountain Regional Transportation System road ....12

\section{Tables}

1. General collection information for voles and small birds captured from three locations in Cape Krusenstern National Monument, Alaska, June and July, 2006.

2. Concentrations of selected metals in blood and liver samples of voles and small birds captured from three locations in Cape Krusenstern National Monument, Alaska, June and July, 2006 


\section{Conversion Factors, Abbreviations, and Datum}

\begin{tabular}{|c|c|c|}
\hline Multiply & By & To obtain \\
\hline \multicolumn{3}{|c|}{ Length } \\
\hline meter (m) & 39.37 & inch (in.) \\
\hline micrometer $(\mu \mathrm{m})$ & 0.00003937 & inch (in.) \\
\hline centimeter $(\mathrm{cm})$ & 0.3937 & inch (in.) \\
\hline kilometer (km) & 0.6214 & mile (mi) \\
\hline \multicolumn{3}{|c|}{ Volume } \\
\hline milliliter $(\mathrm{mL})$ & 0.03382 & ounce, fluid (fl. oz) \\
\hline deciliter $(\mathrm{dL})$ & 0.02642 & gallon (gal) \\
\hline \multicolumn{3}{|c|}{ Mass } \\
\hline $\operatorname{gram}(\mathrm{g})$ & 0.03527 & ounce, avoirdupois (oz) \\
\hline kilogram (kg) & 2.205 & pound avoirdupois (lb) \\
\hline \multicolumn{3}{|c|}{ Chemical constituents } \\
\hline microgram per deciliter $(\mu \mathrm{g} / \mathrm{dL})$ & 0.1 & part per billion (ppb) \\
\hline microgram per liter $(\mu \mathrm{g} / \mathrm{L})$ & 1.0 & part per billion (ppb) \\
\hline milligram per liter (mg/L) & 1.0 & part per million (ppm) \\
\hline microgram per gram $(\mu \mathrm{g} / \mathrm{g})$ & 1.0 & part per million (ppm) \\
\hline
\end{tabular}

Temperature in degrees Celsius $\left({ }^{\circ} \mathrm{C}\right)$ may be converted to degrees Fahrenheit ( $\left.{ }^{\circ} \mathrm{F}\right)$ as follows:

$$
{ }^{\circ} \mathrm{F}=\left(1.8 \mathrm{x}^{\circ} \mathrm{C}\right)+32
$$

Horizontal and vertical coordinate information is referenced to the North American Datum of 1983 (NAD 83).

Concentrations of chemical constituents in solid materials are given in micrograms per gram $(\mu \mathrm{g} / \mathrm{g})$ dry weight. 


\title{
Assessment of Metals Exposure and Sub-Lethal Effects in Voles and Small Birds Captured Near the DeLong Mountain Regional Transportation System Road, Cape Krusenstern National Monument, Alaska, 2006
}

\author{
By William G. Brumbaugh, Miguel A. Mora, and Thomas W. May
}

\section{Abstract}

Voles $(\mathrm{n}=6)$ and small ground-nesting birds $(\mathrm{n}=12)$ were live-captured near the DeLong Mountain Regional Transportation System haul road in Cape Krusenstern National Monument in northwest Alaska in 2006 to assess metals exposure and sub-lethal biological effects. Similar numbers of animals were captured from a reference site in southern Cape Krusenstern National Monument for comparison. Histopathological examination of selected organs, blood analysis, and analysis for aluminum, barium, cadmium, lead, and zinc concentrations in liver and blood samples were performed. Voles and small birds captured from near the haul road had about 20 times greater blood and liver lead concentrations and about 3 times greater cadmium concentrations when compared to those from the reference site. Barium and zinc tissue concentrations of animals collected from different sites were not remarkably different, and aluminum concentrations were below the reporting limits in most samples. There was no clear evidence of serious sub-lethal biological effects such as lesions in internal organs or DNA damage in blood in any of the animals. Accordingly, blood and liver lead concentrations in animals captured near the haul road generally were less than tissue concentration thresholds associated with serious biological effects reported from other studies; however, subtle effects resulting from lead exposure, such as the suppression of the activity of certain enzymes, cannot be ruled out for those animals nearest the haul road. Notably, liver lead concentrations of voles and small birds at the reference location were considerably less than those previously reported for similar animals at reference sites in other parts of the United States, Canada, and Europe. Results from this reconnaissance-level study indicate that voles and small birds inhabiting this area are not suffering serious biological effects as a result of metals exposure; however, continued monitoring of lead and other metals is recommended because of uncertainties noted and because biological effects thresholds might be approached if exposure levels were to increase.

\section{Introduction}

Red Dog Mine, one of the world's largest producers of lead and zinc concentrates, is situated in northwest Alaska approximately 50 kilometers $(\mathrm{km})$ northeast of the boundary of the Cape Krusenstern National Monument (CAKR), one of several National Park Service (NPS) lands managed through the Western Arctic National Parklands (WEAR). Despite the harsh climate of the arctic region, the Red Dog Mine has produced lead and zinc concentrates year-round since it began operation in 1989. After milling and flotation concentration at the mine, the powdered ore concentrates are transported $85 \mathrm{~km}$ by truck by on a haul road to storage facilities on the Chukchi Sea, where they await ocean transport during the brief ice-free shipping period from July to September. The haul road is the primary component of the DeLong Mountain Regional Transportation System (DMTS) that also includes the mine and port facilities (fig. 1); it traverses $32 \mathrm{~km}$ of CAKR land, for which a 100-year transportation easement was granted in 1985 by Congressional approval. Large trucks using the DMTS haul road (henceforth, "DMTS road") to transport lead and zinc concentrates from Red Dog Mine to the shipping facility at Red Dog Port apparently have released quantities of finely-powdered mine concentrates from their loads or exterior surfaces during transport (Alaska Department of Environmental Conservation, 2007). Beginning in 1999, NPS researchers sampled Hylocomium splendens (henceforth, "moss") to document patterns of airborne heavy metal deposition on NPS lands from mining operations at Red Dog Mine. Moss sampled along the haul road corridor in 2000 contained elevated concentrations of cadmium and lead, the source of which was attributed to escapement of ore concentrate from trucks during transport (Ford and Hasselbach, 2001). In a follow-up study, heavy metal concentrations in moss were measured throughout CAKR $(\mathrm{n}=226)$ and geostatistical models were used to predict the extent and pattern of atmospheric deposition of cadmium and lead on NPS lands (Hasselbach and others, 2005). Spatial regression analyses indicated that 

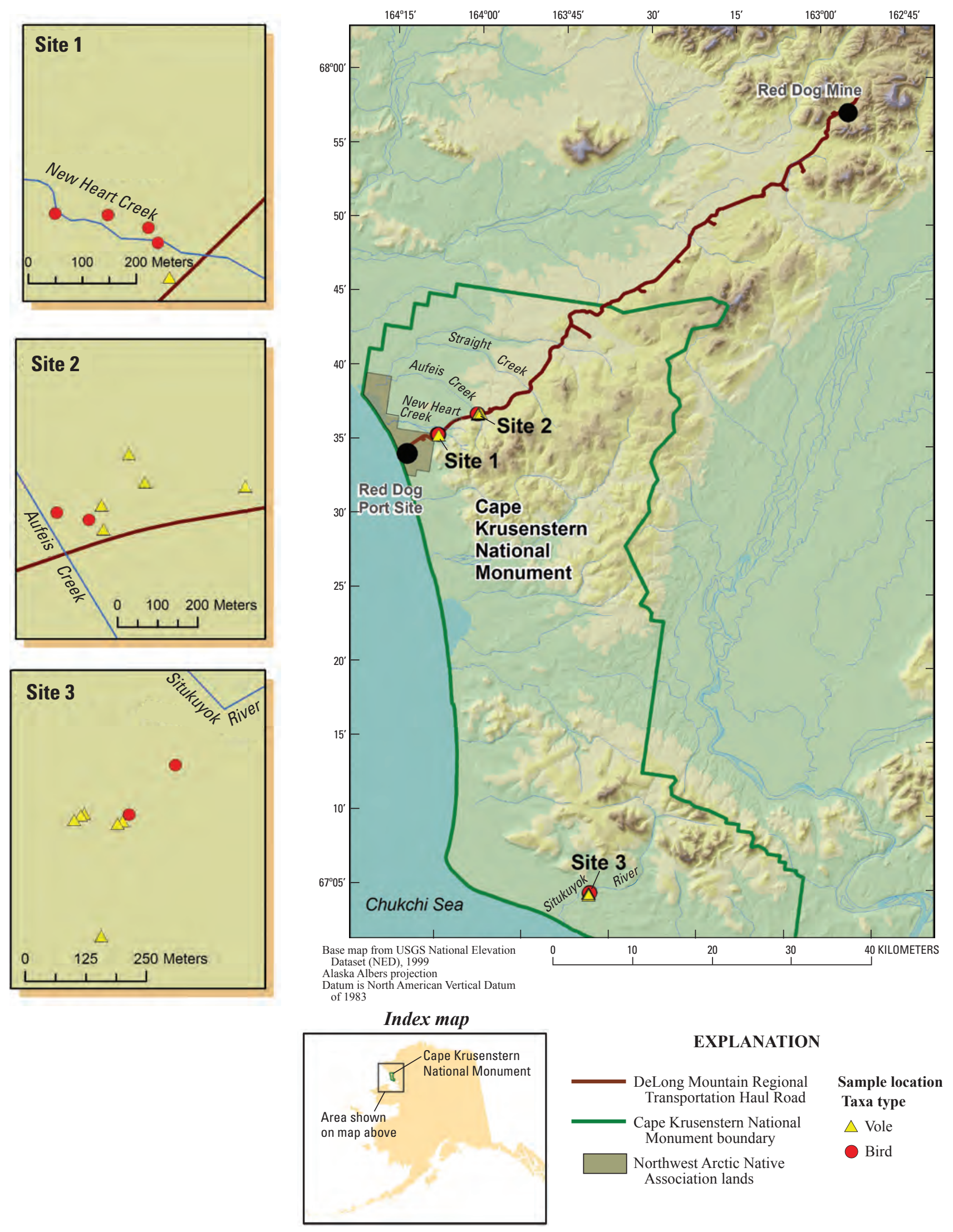

Figure 1. Sampling locations for voles and small birds captured in Cape Krusenstern National Monument, Alaska, 2006. 
heavy metal deposition decreased with distance from the haul road and the port site. Analysis of subsurface soil indicated that observed patterns of heavy metal deposition reflected in moss were not attributable to subsurface soils at the sample points. Further, moss lead concentrations throughout the northern part of the study area were greater than concentrations previously reported for other Arctic Alaska sites. Collectively, these findings indicated the presence of mine-related heavy metal deposition within the northern part of CAKR.

Based on the NPS moss studies, metal bioaccumulation resulting from mining activities could be a long-term issue of concern for managing the CAKR ecosystem. Between 2001 and 2004, with oversight from the Alaska Department of Environmental Conservation (Alaska DEC), a mining company contractor (Exponent), conducted an ecological risk assessment (ERA) on the effects of fugitive dusts associated with the DMTS (Alaska Department of Environmental Conservation, 2007; Exponent, 2007). In brief, Exponent concluded that ecological risks associated with transport of ore concentrates along the DMTS were low to aquatic organisms and to area wildlife populations, but in some instances incremental risks could not be discounted for individual terrestrial organisms nearest the DMTS road.

In the spring of 2006, the U.S. Geological Survey (USGS), in cooperation with NPS researchers, devised a series of inter-related studies designed to address data gaps of the ERA that were of a particular concern for natural resources within CAKR, and to develop strategies for future monitoring. One component of these studies (the focus of this report) was to assess exposure and potential sub-lethal biological effects in small mammals and birds of CAKR. Small animals that forage on terrestrial organisms or vegetation were targeted because they are likely to be at greatest risk from ingestion of fugitive dust either directly or indirectly after uptake by plants and insects. Risks associated with exposure by ingestion tend to be greater in smaller animals because weight-normalized food intake rates tend to increase with decreasing body weights (U.S. Environmental Protection Agency, 1993). Areas along the haul road in the northwestern part of CAKR were targeted based on previous studies that indicated that metal deposition within CAKR was greatest along the road and nearest to the port site (Hasselbach and others, 2005).

\section{Purpose and Scope}

The purpose of this report is to provide results for blood and liver metals concentrations, and histopathological examinations and other measures, to assess biological effects in voles and small ground-nesting birds that could be associated with increased metals exposure near the DMTS haul road in CAKR, Alaska. The scope is limited to a small number of organisms and three sampling locations, and therefore represents only a reconnaissance-level assessment.

\section{Methods}

\section{Sampling Design and Field Procedures}

Animals were collected from three general areas that included two locations just north of the haul road along New Heart and Aufeis Creeks, and one reference location near the Situkuyok River in southern CAKR (fig. 1). The reference area was chosen based on being a similar distance from the coast, having similar vegetative cover (willow shrub near waterways and mostly mixed-shrub tussock tundra elsewhere), and being far enough south of the DMTS road to effectively rule out the possibility that metal-enriched fugitive dusts might be reaching that area. Areas north of the haul road are subject to greater contamination from fugitive dusts because of prevailing southerly winds, whereas based on model predictions, metals including cadmium and lead could be slightly elevated to as far south as approximately the mid-section of CAKR (Hasselbach and others, 2005). Sampling at the DMTS road sites was to include locations of up to $200 \mathrm{~m}$ from the road, but distances of less than $100 \mathrm{~m}$ were emphasized to increase the likelihood of measuring sub-lethal biological effects. Metals, including aluminum, barium, cadmium, lead, and zinc specifically were targeted for this investigation based on information from previous ecological investigations (Exponent, 2007). Dust originating from road aggregate material and possibly from ore waste rock were the presumed sources of aluminum and barium, whereas fugitive dusts from mining wastes and transported mining concentrates were the presumed sources of cadmium, lead, and zinc. Haul-road sites were sampled June 21-29, 2006 and the reference site was sampled July 2-5, 2006. Blood was drawn from each specimen for analysis for metal concentrations and selected biochemical measurements. All animals were then dissected and selected organs were sectioned and preserved for histopathological examination and analysis for metal concentrations. All animal collection and handling procedures followed those described by the Ornithological Council, (1999) or Gannon and others, (2007).

Initially, four animal categories were targeted for study, including herbivorous bird (primarily willow ptarmigan, Lagopus lagopus); insectivorous small mammals, such as cinereus shrew (Sorex cinereus) or tundra shrew (Sorex tundrensis); insectivorous small ground-nesting birds, such as lapland longspur (Calcarius lapponicus), American tree sparrow (Spizella arborea), or savannah sparrow (Passerculus sandwichensis); and herbivorous/omnivorous rodents, such as redbacked vole (Clethrionomys rutilus) or tundra vole (Microtus oеconomus). All of these targeted species are among the most common of their respective animal categories within CAKR. The study goal was to capture at least six individuals of each of the four animal categories from each of the three general locations; however, logistical problems and time constraints prevented the collection of sufficient numbers of ptarmigan or shrews. 
The willow ptarmigan is the primary resident avian species of CAKR and was targeted in this investigation because it previously was identified as an important terrestrial avian herbivore species potentially at-risk (Exponent, 2007). However, efforts to collect them (by shooting) were soon abandoned because their numbers appeared to be low in the areas of study and in addition, successful shooting without the benefit of a hunting dog proved to be difficult. Only four ptarmigan were encountered during nine field days near the haul road-one pair each in New Heart and Aufeis Creek Basins. Each pair was encountered near the creek at about 500 meters $(\mathrm{m})$ north of the road and appeared to be nesting. Shrews were presumed to be present in reasonable numbers, but only four could be obtained (using pitfall traps) and three were from the reference site. All four shrews were deceased when recovered, which precluded sampling of blood for biochemical or metals analyses.

Numbers of collected specimens were close to the targets for all three sampling locations for the birds, and at two of the three locations for the rodents (table 1). However, only one vole was captured at the New Heart Creek location, and insufficient blood was obtained for analysis for metals for two of the four birds obtained near Aufeis Creek and five of the eight birds from the reference location. Weather conditions were cold and rainy during the first several days of sampling, which probably suppressed foraging activity and contributed to poor capture success of voles at the New Heart Creek location (Amy Runck, Idaho State University, oral commun., 2006; however, it also is possible that low numbers of voles were present at that location.

Sherman traps baited with peanut butter and oats were used to capture voles, whereas mist nets were used for small birds. At each site, about 100 Sherman traps were set on the first day and 150 for each of the remaining days (up to four days total). Traps were set with fresh bait in the evening and checked the following morning. Trap placement focused on mesic tussock/dwarf birch micro habitats where vole runs (trails) were evident. After the second day all traps were moved to another locale (typically about $50 \mathrm{~m}$ away), and most were relocated once again after the third day. At the two DTMS road sites, approximately two thirds of the traps were placed between 10 and $100 \mathrm{~m}$ from the road, and the remainder placed between 100 and $200 \mathrm{~m}$ away. Vole runs were not apparent at distances of less than $10 \mathrm{~m}$ from the road at these locations, presumably because the habitat nearest the road was disrupted by the presence of the road berm and because of visible dust coating the vegetation. Mist nets were set in the mornings and evenings to coincide with periods of greatest bird activity and were checked approximately every 30 minutes; each captured bird was held in a nylon stocking for transport to a nearby tent for processing. Mist nets were set directly adjacent to the creeks, which had taller willow and shrub vegetation that seemed to be favored by many of these birds, at nominal distances of 50, 100, 150, and $200 \mathrm{~m}$ from the DMTS road. All animals obtained from the two DMTS sites were captured between 12 and $200 \mathrm{~m}$ to the north of the haul road (table 1).

Voles and birds were processed inside a large tent set up about $150 \mathrm{~m}$ from the DMTS road. Powder-free laboratory gloves were worn during processing. Animals were weighed with a pesola scale and body mass and body condition were recorded. Between 0.5 and 1.0 milliliter $(\mathrm{mL})$ of blood was collected from the jugular vein with a $1-\mathrm{mL}$ tuberculin syringe and 25-gauge needle. In some instances a heart puncture (after euthanasia) using a 20-gauge needle was necessary to obtain blood. About five drops of whole blood were transferred to a cryogenic vial containing a commercially-available sorter media for flow cytometry analysis, and stored on dry ice. Another five to six drops were dispensed into a pre-weighed, acid-cleaned, 10-mL borosilicate glass test tube fitted with a tetrafluoroethylene (TFE)-lined polyethylene screw cap for metals determination (also placed on dry ice). Any remaining blood was dispensed into a cryogenic vial and placed on dry ice for potential analysis for $\delta$-aminolevulinic-acid dehydratase (ALAD; Finelli, 1977) and hemoglobin content. Immediately after blood collection, birds were euthanized by cervical dislocation and mammals by thoracic compression under approved animal use protocols. Each animal was then immediately dissected for tissue collection following general procedures of the USGS Biomonitoring of Environmental Status and Trends (BEST) program (Schmitt and others, 1999) and MacDonald and Cook (2002). Two sets of stainless steel surgical instruments were used for animal dissection; one for opening the body cavity and the second for removal of the internal organs. Between samples, all instruments were wiped with a lint-free laboratory tissue and rinsed with isopropyl alcohol.

A section of each liver and kidney and the whole spleen were transferred to vials containing a buffered formalin preservative at ambient temperature for histopathology analysis. Samples were thus preserved within 10 to 15 minutes of animal death. The remainder of each liver and kidney tissue, as well as a femur (voles) or tibia (birds) bone, were each transferred to a separate chemically-cleaned cryogenic vial and stored on dry ice for shipment to the laboratory for trace metal analyses. Generally, the section of liver portioned for the metals analysis represented about one-half of the whole organ; consequently, results for the sub-sampled portion might not have been completely representative of the entire liver if metal concentrations were heterogeneously distributed. A few breast feathers from birds and a tuft of fur from mammals was collected from each individual and stored separately in a zipseal bag. Finally, the remaining carcass was placed in a heavy duty plastic bag, sealed with elimination of surrounding air, and stored on dry ice. All specimens except those in the liquid preservative were shipped with dry ice to the USGS laboratory in Columbia, Missouri, for archival and possible analysis for metal contents. Accompanying each shipment of samples were completed USGS sample batch history and chain-ofcustody forms. 
Table 1. General collection information for voles and small birds captured from three locations in Cape Krusenstern National Monument, Alaska, June and July, 2006.

[Distance is from edge of road berm and is approximate for birds. ID, identification; N, north; W, west; DMTS, DeLong Mountain Regional Transportation System; --, not applicable]

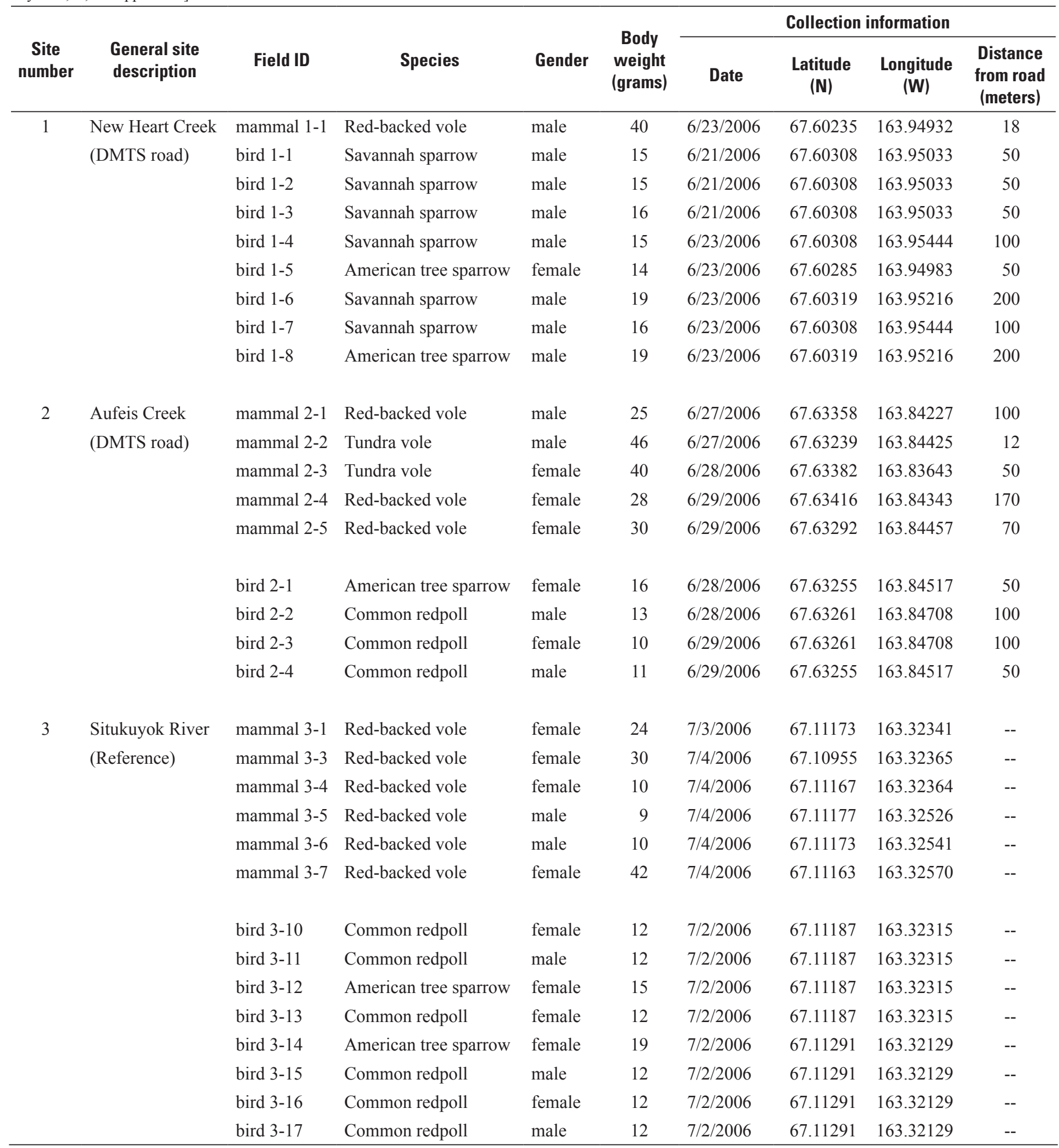




\section{Laboratory Procedures for Determination of Metals}

Liver, kidney, and blood samples were lyophilized (freeze-dried) to a constant dry weight in their collection containers. Feathers, fur, and bone samples were stored in a freezer for future analysis. Kidney samples designated for metals determinations were not analyzed because the dry mass available for most of the bird samples was insufficient [less than 0.01 gram $(\mathrm{g})$ ] to perform a consistent analysis. Following lyophilization, the pre-weighed test tubes containing dried blood samples were re-weighed to determine dry blood masses. Dried liver samples were pulverized briefly with an acid-cleaned glass rod to a powder-like consistency. Digestion of dried blood was performed by heating each sample in its respective collection tube with nitric acid $\left(\mathrm{HNO}_{3}\right)$ and hydrogen peroxide $\left(\mathrm{H}_{2} \mathrm{O}_{2}\right)$. First, $1.0 \mathrm{~mL}$ of concentrated, sub-boiling distilled $\mathrm{HNO}_{3}$ was added to each blood sample. After 1 hour the cap was tightened and each tube was placed for 30 minutes in a small dry-block well heater set at 110 degrees Celsius $\left({ }^{\circ} \mathrm{C}\right)$. Tubes were removed from the block and after cooling for 15 minutes, $0.2 \mathrm{~mL}$ of high-purity 30 percent $(\mathrm{v} / \mathrm{v}) \mathrm{H}_{2} \mathrm{O}_{2}$ was added to each. The tubes were then resealed, returned to the block heater for 30 minutes, cooled, and the volume of each was adjusted to $10 \mathrm{~mL}$ with ultrapure water. A part of each dried liver sample (0.05-0.4 $\mathrm{g}$ for voles; 0.017-0.098 $\mathrm{g}$ for birds) was digested in a sealable TFE-lined vessel to which $6 \mathrm{~mL}$ concentrated $\mathrm{HNO}_{3}$ and $1 \mathrm{~mL} 30$ percent ( $\mathrm{v} / \mathrm{v}$ ) high-purity $\mathrm{H}_{2} \mathrm{O}_{2}$ were added. After 30 minutes the vessel was sealed and heated to 190 plus or minus $( \pm) 10^{\circ} \mathrm{C}$ in a microwave oven. The digestate was cooled and quantitatively transferred to a low-density polyethylene bottle and diluted with ultrapure water to a $100-\mathrm{mL}$ volume.

\section{Instrumental Analysis and Data Reporting}

Analysis of the sample digestates for trace elements was conducted by inductively coupled plasma mass spectrometry (ICP-MS) for aluminum (Al), barium (Ba), cadmium (Cd), lead $(\mathrm{Pb})$, and zinc $(\mathrm{Zn})$ according to instrument manufacturer recommendations and United States Environmental Protection Agency (USEPA) quality assurance guidelines (U.S. Environmental Protection Agency, 1996a).

Each sample digestate was pre-diluted by a factor of ten by an auto-diluter system. Solutions of scandium, rhodium, and bismuth were metered in the sample line for use as internal standards to correct for small fluctuations in ionization efficiencies caused by sample constituents or other factors. Instrument calibration was performed for each targeted mass with at least four standard concentrations, and blank and calibration check standards were monitored periodically for each element. Atomic masses monitored included ${ }^{27} \mathrm{Al},{ }^{65} \mathrm{Zn}$, ${ }^{68} \mathrm{Zn},{ }^{111} \mathrm{Cd},{ }^{114} \mathrm{Cd},{ }^{138} \mathrm{Ba}$, and ${ }^{206+207+208} \mathrm{~Pb}$. All lead isotopes were summed to correct for local and regional variation in the isotopic composition of that element. Results were reported based on individual masses for cadmium and zinc, depending upon performance of quality assurance samples and the degree of apparent interferences observed during the sample analyses. Minimal differences were observed between final results based on ${ }^{65} \mathrm{Zn}$ or ${ }^{68} \mathrm{Zn}$, and ${ }^{111} \mathrm{Cd}$ or ${ }^{114} \mathrm{Cd}$, indicating that either mass could have been used for accurate quantitation for these two elements. All liver and whole blood elemental concentrations are reported on a dry weight basis. In addition, blood-lead concentrations were converted to micrograms per deciliter equivalents assuming 85 percent water content and a density of 1.05 grams per milliliter $(\mathrm{g} / \mathrm{mL})$. Measured concentrations of aluminum in liver samples were not particularly informative because all results were comparatively low and because method blanks contained measurable concentrations of aluminum that increased the reporting limit for that element (discussed later). Consequently, statistical analyses were performed using only the results for barium, cadmium, lead, and zinc.

\section{Quality-Control Results for Metals}

For each group of samples analyzed, quality-control (QC) measures incorporated at the digestion step included three to five method blanks (three with blood sample digestions; five with liver sample digestions), certified reference materials (freeze-dried liver tissue or blood), replicate samples, and fortified samples (pre-digestion spikes). Because the mass of blood and liver samples of CAKR specimens available for metals determinations was limited, reference tissue samples were used to prepare replicated and spiked samples for QC purposes. Additional QC monitoring during the ICP-MS analyses included periodic analyses of blanks and calibration check solutions, duplicate analyses of selected sample digestates, post-digestion (analysis) spikes, and interference checks (sample dilution analysis and a synthetic interference solution). Target limits for accuracy during instrumental analysis were \pm 10 percent error. Target limits for mean recovery of pre-digestion spikes and post-digestion spikes were 75 to 125 percent and 85 to 115 percent, respectively. Target limits for precision were \pm 10 percent repeatability, expressed as relative percent difference (RPD) or relative standard deviation (RSD) for instrumental analysis and \pm 25 percent repeatability for digestion replicates. Results for certified reference tissues, replicated samples, and pre-digestion spikes are summarized in appendices A, B, and C at the back of this report. A complete summary of QC results, consisting of 22 data tables, are available upon request from the USGS Columbia Environmental Research Laboratory, 4200 New Haven Road, Columbia, Missouri, USA, 65201.

Results for QC samples indicated acceptable precision and accuracy for barium, cadmium, lead, and zinc, but problems were evident for aluminum. Accurate measurement of aluminum in tissue samples has been categorized as an extremely difficult analysis because of the low concentrations and the ubiquitous nature of this element, so much so that the U.S. National Institute of Standards and Technology (NIST) 
has historically had difficulties producing a biological material certified for aluminum content (Blotcky and others, 1992). Based on the QC results (discussion follows), the aluminum data only can be considered semi-quantitative; furthermore, the concentrations in procedural blanks coupled with the small tissue masses analyzed resulted in aluminum reporting limits that were greater than the measured concentrations of most samples. Accordingly, specialized techniques tailored specifically for ultra-trace aluminum concentrations might be needed to accurately assess aluminum concentrations in blood and tissues of biota from CAKR.

Aside from one lower recovery for lead ( 82 percent), mean recoveries of cadmium, lead, and zinc ranged from 92 to 112 percent in four certified reference tissues that included one each of liver, oyster, and whole fish tissue, and one synthetic gelatin matrix (appendix A). Recoveries of cadmium, lead, and zinc in three blood reference samples ranged from 89 to 109 percent. Recovery of barium was 90 percent from the one material for which a certified value is reported. Recovery of aluminum was less consistent $(61,81$, and 100 percent in the three reference tissues for which a certified value is reported). The low recovery of aluminum in the oyster reference sample (61 percent) was in agreement with past measurements conducted at the laboratory, and was presumed to be caused in part by insoluble matter that is present in that sample. Certified values reported by the NIST were obtained using a total dissolution procedure, which includes all insoluble matter, whereas the total recoverable procedure used at the laboratory does not recover elements from refractory minerals and some forms of insoluble matter (Brumbaugh and May, 2008).

Aside from one lower recovery for zinc ( 83 percent), the range of individual pre-digestion spike recoveries of barium, cadmium, lead, and zinc added to a reference liver or blood sample was 91 to 105 percent (appendix B). Results for aluminum in pre-digestion spikes were less consistent (mean recovery of 86 percent; standard error of 17 percent) indicating that the measurement of that element was not as precise and accurate as the other four. This can be attributed mostly to variability of aluminum in the digestion blanks, which adversely affected the measurement of most sample concentrations and subsequently elevated the method detection limit for that element [about 4 micrograms per gram $(\mu \mathrm{g} / \mathrm{g})$ in blood and $26 \mu \mathrm{g} / \mathrm{g}$ in liver samples; discussed later]. Accordingly, the three poorest spike recoveries for aluminum $(19,57$, and 131 percent) were obtained from each of the three "low" fortified spiked samples (about $20 \mu \mathrm{g} / \mathrm{g}$; appendix B).

The range of relative standard deviations (RSDs) for triplicate determinations of cadmium, lead, and zinc (digestion and analyses) of three reference tissues was 0.6 to 3.9 percent (appendix C). Vole or bird liver tissues could not be replicated because there were insufficient amounts of any sample available. One vole blood sample (from the reference site) was prepared and analyzed in duplicate. However, zinc was the only element in that sample that was of a greater concentration than the corresponding method quantitation limit, and for that the relative difference between duplicate preparations was
7.4 percent (appendix C). Method variability (digestion and analysis) was much greater among replicate determinations for aluminum and to a lesser extent, barium; however, the RSDs for these two elements were outside the \pm 25 percent target only in the replicated reference sample that contained the lowest concentrations (NIST reference material number 1577). Variable concentrations of aluminum in the digestion blanks combined with the low concentrations in samples undoubtedly contributed to the greater relative variability observed for this element.

Duplicate instrumental analyses of four separate digestate solutions for aluminum, barium, cadmium, lead, and zinc yielded a range of relative differences of 0.1 to 2.0 percent for blood samples, and 0.1 to 2.3 percent for liver samples (data not shown), indicating that within-run instrumental precision was excellent for all five elements. Method detection limits (MDLs) were estimated for each of the two sample types (two digestion methods) based on three times the standard deviation of the digestion blanks, which was converted to a dry weight equivalent concentration by multiplying by the final dilution volume and dividing by the average sample weight digested. The MDLs in $\mu \mathrm{g} / \mathrm{g}$ dry weight equivalents for blood and liver, respectively, were: aluminum $-4.0,26$; barium $-0.03,0.08$; zinc - 1.0, 0.7; cadmium -0.0008, 0.009; and lead -0.003 , 0.01 . Except for aluminum, blank equivalent concentrations (BECs) of digestion blanks (eight in all) were all near or less than the corresponding MDLs (data not shown). Aluminum concentrations in digestion blank solutions ranged from 20 to 60 micrograms per liter $(\mu \mathrm{g} / \mathrm{L})$; the source was determined to originate from the lot of nitric acid used for sample digestion, as well as leaching from container surfaces during digestion. Consequently, the reporting limit for aluminum was greater than what might be achieved under ideal conditions.

\section{Tissue and Blood Examination Procedures}

The following tissues from 20 birds and 18 mammals were examined: liver, kidney, ovary or testes, spleen, skeletal muscle, and ventriculus (from birds). Additionally, the pancreas of three and uterus of two mammals were analyzed. The tissues were sectioned and prepared for examination for lesions or other abnormalities according to established procedures at the School of Veterinary Medicine, Texas A\&M University (Saggese and others, 2007). Briefly, tissues were fixed in neutral buffered formalin, paraffin embedded, and sectioned at 4 micrometers $(\mu \mathrm{m})$. Deparaffinized tissues were then routinely stained with haematoxyln and eosin.

All slides were read blind by individuals with no previous knowledge of sample history. The quality of the tissue sections and the preservation of the tissues were excellent. Spleen sections were missing from several of the birds because of difficulties in collecting them in the field at the time of tissue collection. Histological examination was done on stomachs from voles and evaluated in glandular and nonglandular regions, but histological preparations in these preliminary readings were limited to one region or the other in any given individual vole. 
The DNA of bird blood and mammal femur samples was analyzed by flow cytometry to detect possible DNA damage as reflected by an increase in the half peak coefficient of variation (HPCV) of DNA content (Bickham, 1990, Custer and others, 1994). Analyses were conducted at the Center for the Environment, Purdue University, Lafayette, Indiana. Blood also was to be analyzed for ALAD activity, but for many of the specimens insufficient blood was obtained to conduct this determination. Furthermore, some samples apparently did not remain completely frozen during shipment; consequently, analysis for ALAD was judged to be unreliable.

\section{Specimens Collected and Statistical Analysis}

Vole and small bird species captured at Aufeis Creek and New Heart Creek near the DMTS road were not unlike those captured at the reference location (table 1). Vole collections were dominated by northern red-backed vole (Clethrionmys ritilus, 10 individuals), followed by tundra vole (Microtus oeconomus, two individuals) the latter of which were both captured from near Aufeis Creek. Small birds (neotropical migrants) captured included common redpoll (Carduelis flammea, nine individuals), savannah sparrow (Passerculus sandwichensis, six individuals), and American tree sparrow (Spizella arborea, five individuals). Birds collected from near New Heart Creek were dominated by savannah sparrow, whereas a mix of common redpoll and American tree sparrow were obtained from near Aufeis Creek and the Situkuyok River (table 1).

Three levels of statistical comparisons were performed between metal concentrations in blood or liver tissues of either voles or of birds collected from near the DMTS road to their vole or bird counterparts obtained from the reference location. Because of heterogeneous variance, all concentrations were $\log _{10}$-transformed for the analyses. For comparison at the first level, metals data for both vole species were pooled, and data for all three bird species were pooled for each of two site categories. This analysis might be considered most relevant for potential food-chain metal transfers where voles collectively or small birds collectively are considered as potential prey to higher-order predators. The second level of analysis focused only on the most frequently collected vole or bird species obtained from both of the two site categories; in this instance, the red-backed vole and the common redpoll. Although pooling species in broad groupings as "voles" and "birds" offsets sample-size constraints in a reconnaissance level analysis, it introduces assumptions regarding the data distributions of each species in the data pool, and potential differences in species-specific attributes affecting bioaccumulation of metals. Consequently, a comparison using a single common species was preferable for identifying site differences. Finally, a third level of analysis was performed for the red-backed vole that excluded the three smallest specimens from the reference site because those animals (body weights of 10, 9, and $10 \mathrm{~g}$ ) apparently were juveniles (table 1).
For pooled data, 32 liver samples were included in the analysis (20 bird and 12 vole); whereas for blood a total of only 22 samples were included (11 vole and 11 bird) because for some blood samples there was insufficient sample mass for analysis. For each level of analysis, an analysis of variance was run using the General Linear Model (GLM) procedure in SAS/STAT ${ }^{\circledR} 9.1$ (SAS Institute, Inc, 2004). The GLM contained the effects of species, site category, and the interaction of species and site category. Mean differences were determined using Fisher's protected least significant difference method. The power of the statistical tests was limited greatly by the small sample sizes.

\section{Results and Discussion}

\section{Metal Concentrations in Blood and Liver}

Blood and liver metal concentrations are provided in table 2. For vole blood metal concentrations, only lead was significantly greater in blood of animals obtained from near the DMTS road $(n=5)$ when compared to the reference site $(\mathrm{n}=6)$, but the difference was highly significant $(\mathrm{p}<0.0001)$. Similar results were obtained if only red-backed voles were considered, either with or without juvenile animals included (table 2). When blood data from all small bird species was pooled, cadmium and lead concentrations were significantly greater in birds obtained from near the DMTS road as compared with the reference site ( $p<0.05$ and $<0.0001$, respectively), but there were no significant differences for barium and zinc (table 2). There was insufficient data to allow for a comparison between the DMTS road and the reference site using blood concentrations of a single bird species.

For vole liver metal concentrations, cadmium and lead were significantly greater in animals obtained from near the DMTS road as compared with reference site $(\mathrm{p}<0.001$ and $<0.0001$, respectively; table 2). As was true for blood, similar statistical differences were obtained when only the red-backed vole was considered, either with or without juveniles included; however, juveniles (obtained only from the reference site) tended to have lower cadmium and barium liver concentrations than the adults (table 2). For small birds, there were significant differences between liver metal concentrations of those obtained near the DMTS road and the reference site for cadmium ( $\mathrm{p}<0.05)$, barium $(\mathrm{p}<0.01)$, and lead $(\mathrm{p}<0.0001)$, but not for zinc. When only the common redpoll was considered, statistical differences for barium and lead liver concentrations were comparable to that of the pooled data, but the difference was no longer significant for cadmium (table 2). The latter result might have been greatly affected by the small sample size $(\mathrm{n}=3)$ for common redpoll at the DMTS road site.

Lead clearly was the most elevated metal measured in animals captured near the DMTS road. Blood and liver mean lead concentrations in voles and birds captured near the DMTS road and in the reference area are contrasted in figure 2. Both 


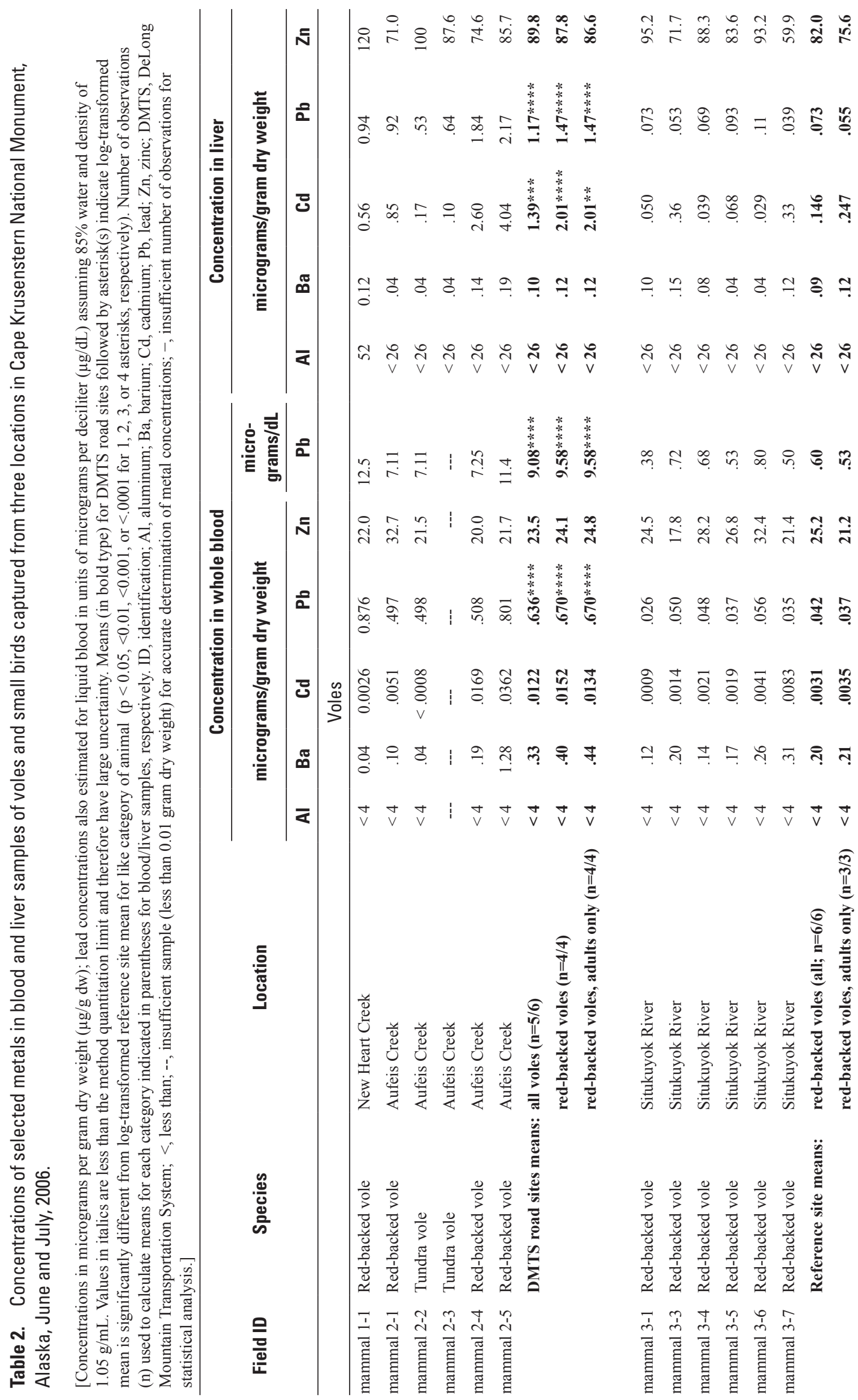




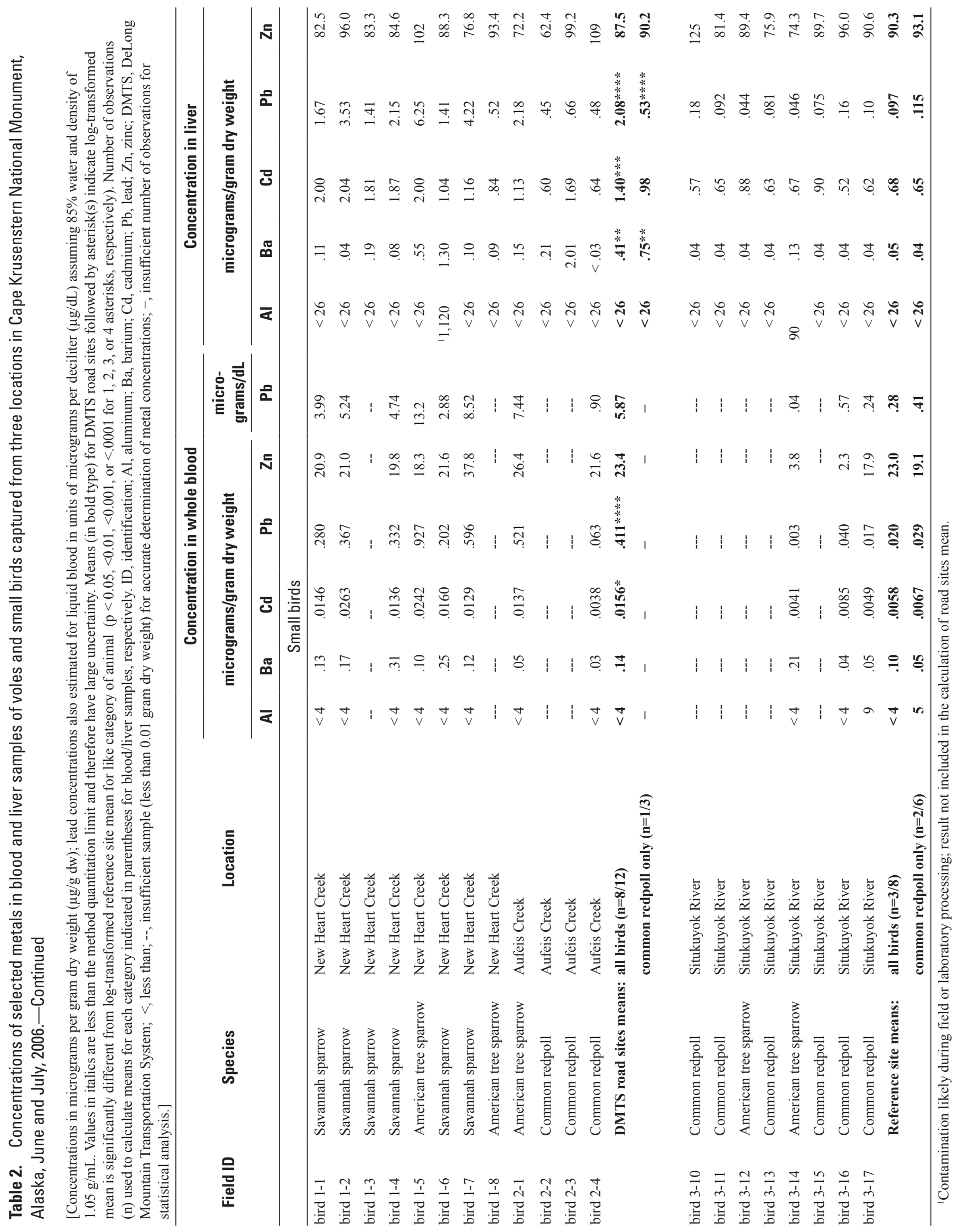



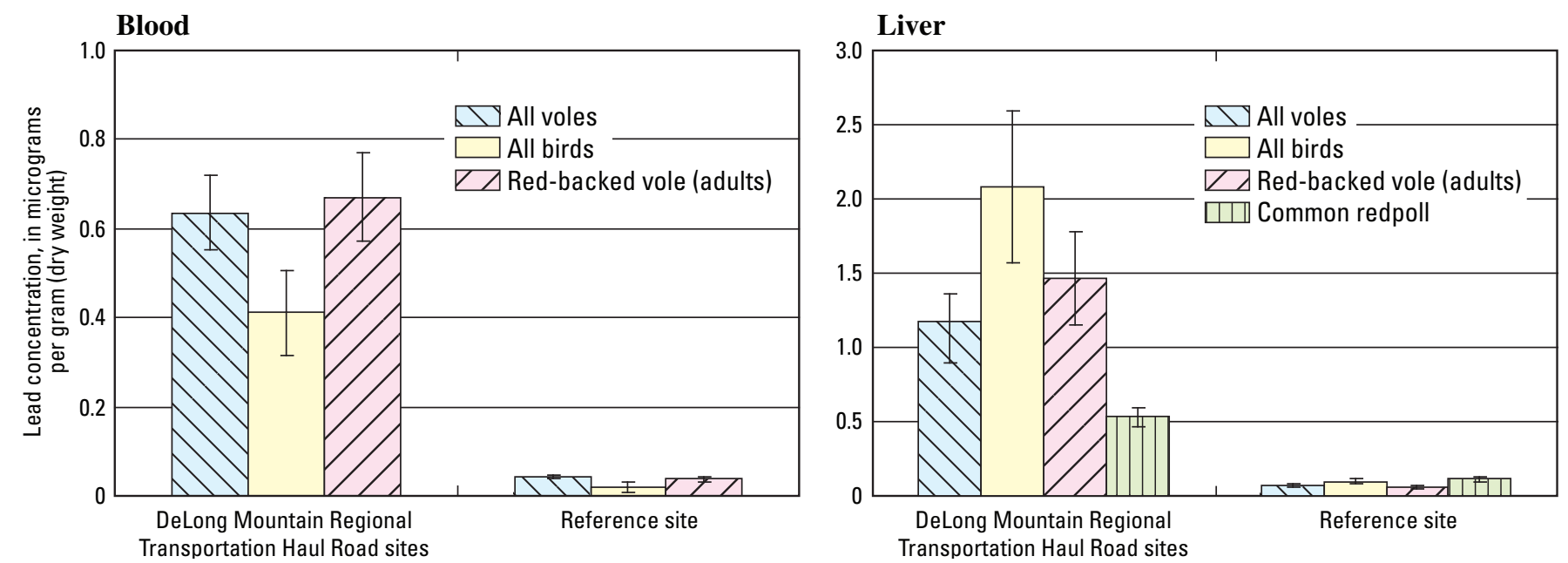

Figure 2. Comparison between blood and liver lead concentrations in voles and small birds captured near the DeLong Mountain Regional Transportation System road to those from a reference location. Error bars are plus or minus one standard error.

voles and small birds captured from near the DMTS road had blood and liver lead concentrations that were greater on average by factors of about 16 to 20 as compared with the reference location. The next greatest differences were for cadmium, which was elevated by a factor of about three in tissues of birds and voles captured near the DMTS road (table 2). Mean blood lead concentrations of animals obtained near the road were about 50 percent greater in voles than in small birds, but the opposite trend was observed for liver lead concentrations. Lead concentrations in livers were much more variable among individual birds than in voles, perhaps because not all of the birds had arrived at the same time, and also because of greater potential dietary differences among the three species collected. Most migratory birds typically arrive in this region sometime in mid-May (Anderson, 1994); therefore, the birds probably only had inhabited the area for about 6 weeks before their capture in late June. The finding that small birds that presumably had been present for just a few weeks had blood and liver lead concentrations that were elevated to similar levels of the resident voles was somewhat surprising, because voles do not hibernate and should have foraged periodically throughout the winter (Osborne, 1994).

It is possible that blood-lead concentrations had reached a near steady-state in the birds after only 6 weeks of exposure, but otherwise dietary preferences and greater food consumption rates might partly explain the apparent greater assimilation of lead in the small birds as compared to the voles. For example, Ma and others (1991) observed that common shrews (Sorex araneus), which had consumed mostly earthworms, spiders, and beetles, had accumulated much greater body burdens of cadmium and lead from metal-contaminated soils as compared to field voles (Microtus agrestis), which had consumed mostly grasses and mosses. During breeding season, a large fraction of the diet of sparrows typically consists of insects (Anderson, 1994; Knox and Lowther, 2008; Naugler, 1993; Wheelwright and Rising, 1993) whereas voles, particularly the Microtus genus, typically consume mostly vegetation (Osborne, 1994).

Potential differences in metals concentrations between species and distances from the road could not be compared statistically because of insufficient sample numbers, so a simple graphical comparison was used to evaluate these factors in a preliminary manner. Blood and liver lead concentrations for all animals obtained from near the DMTS road were plotted individually according to capture distance from the road (fig. 3). There were no obvious differences between concentrations of lead in tissues of birds (open symbols) captured from about 50 or $100 \mathrm{~m}$ away from the road, but the two sparrows captured from about $200 \mathrm{~m}$ away (two superimposed symbols in the figure) had lower lead concentrations than the other sparrows obtained from DMTS locations. The birds probably occupied breeding territories encompassing linear distances of at least $100 \mathrm{~m}$, so the absence of differences between those captured at distances of 50 or $100 \mathrm{~m}$ is not surprising. Among the birds sampled, common redpolls accumulated the lowest concentrations of lead (fig. 3), an observation that is consistent with expectations based on dietary-related differences of metal assimilation for ground-dwelling animals noted previously. Common redpolls are smaller, finch-like birds that prefer mostly seeds (Knox and Lowther, 2008), whereas sparrows tend to target mostly insects (Wheelwright and Rising, 1993). A similar tendency for putative dietary differences was evident between the two voles species collected. Tundra voles $(n=2)$ tended to have lower concentrations of lead in the blood and liver than did red-backed voles, regardless of capture distance (fig. 3), and they also had lower cadmium concentrations (table 2). Tundra voles reportedly are primarily herbivorous, whereas red-backed voles are at times omnivorous (Osborne, 1994). There was no apparent trend of lead concentration in vole livers with capture distance among these few samples, but blood-lead concentrations of the red-backed voles $(n=4)$ followed a general pattern of decreasing concentration with 
increasing capture distance from the road (fig. 3 blood, solid squares).

Notably, arithmetic mean liver lead concentrations measured in voles and small birds collected from the CAKR reference site ( 0.073 and $0.097 \mu \mathrm{g} / \mathrm{g}$ dry weight, respectively) were considerably less than concentrations previously reported at several reference sites in other regions. For example, trace metal data compiled for voles in studies conducted between 1972 and 1989 at putative reference sites in other parts of the United States, Canada, and Europe included liver lead concentrations that ranged from 2.8 to $12 \mu \mathrm{g} / \mathrm{g}$ dry weight for Clethrionomys glareolus, and 1 to $6 \mu \mathrm{g} / \mathrm{g}$ dry weight for three Microtus species (Talmage and Walton, 1991). Getz and others (1977) reported the mean liver lead concentration of rural house sparrows (Passer domesticus) as $0.6 \mu \mathrm{g} / \mathrm{g}$ dry weight, or about 6 times greater than in sparrows obtained from the reference location in CAKR. Liver lead concentrations in voles and sparrows at reference locations for these pre-1990 studies might have been affected by residual atmospheric lead originating from historic uses as a gasoline additive through the 1970s, whereas the remoteness of the reference location in southern CAKR might have been less affected by any anthropogenic sources of lead. In addition, much of the pre-1990 data might have been biased as a result of external contamination (Settle and Patterson, 1976) and because ultra-trace sampling techniques (U.S. Environmental Protection Agency, 1996b) were not used routinely. Finally, greater sensitivity for the ICP-MS method, when compared with most pre-1990 methods, might have allowed for increased accuracy for lead concentrations less than $0.1 \mu \mathrm{g} / \mathrm{g}$ dry weight. Liver lead concentrations reported in rodents from control sites in more recent studies included means of about $0.4 \mu \mathrm{g} / \mathrm{g}$ dry weight for white-footed mice (Stansley and Roscoe, 1996), and $0.11 \mu \mathrm{g} / \mathrm{g}$ dry weight for yellow-necked mice (Damek-Poprawa and Sawicka-Kapusta, 2003).

Concentrations of barium and zinc in livers were not significantly different among voles collected from different locations, and aluminum concentrations were below the reporting limits in all but one sample (table 2). Based on previous documentation that zinc concentrations were elevated in mosses near the DMTS road (Ford and Hasselbach, 2001), increased exposure to zinc was presumed for animals collected from near the DMTS road; however, the absence of increased blood or liver zinc concentrations when compared with animals from the reference location was not surprising. Zinc tissue concentrations are regulated internally by most vertebrates unless the zinc dose is extraordinary (Talmage and Walton, 1991). Although acute zinc poisoning in wildlife seldom has been documented, in one case waterfowl suffering from pancreatitis presumed to be caused by consumption of mine waste water containing greatly elevated concentrations of zinc had liver concentrations of at least $280 \mu \mathrm{g} / \mathrm{g}$ dry weight (Sileo and others, 2004), or about three times greater than liver zinc concentrations of passerine birds from CAKR. Mean liver barium concentrations of CAKR birds from the DMTS locations were significantly greater than those of the reference location, but variability was large among concentrations of near-road bird samples ( 0.04 to $2.0 \mu \mathrm{g} / \mathrm{g}$ dry weight). Variability might have been caused in part by low-level random contamination during dissection that originated from dust on the birds feathers or from other sources, and the relative error caused by any such external contamination would have been magnified by the comparatively small mass of bird liver samples used to determine the concentrations $(0.02$ to $0.1 \mathrm{~g})$. The absence of significant differences of barium concentrations among vole blood or liver tissues, or in bird blood samples tends to support

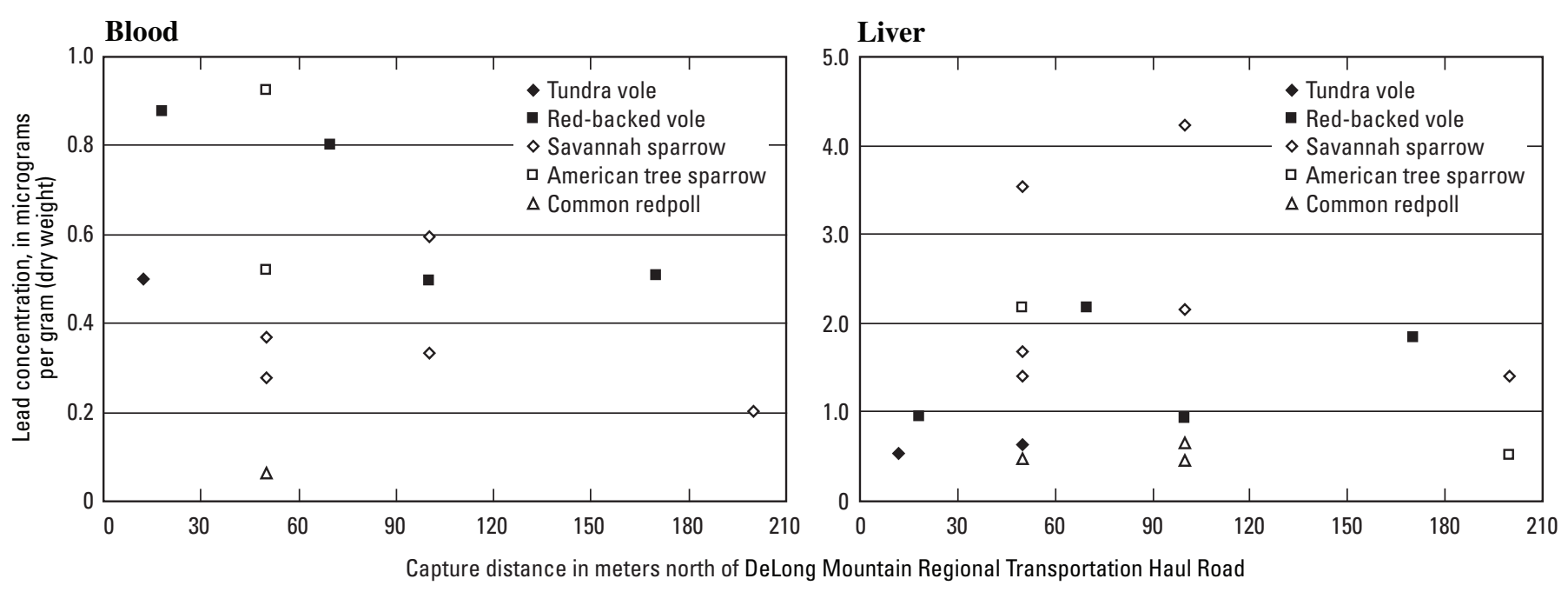

Figure 3. Blood and liver lead concentration in voles and small birds plotted according to capture distance from the DeLong Mountain Regional Transportation System road. 
this possibility. The fact that no significant site differences were observed between zinc concentrations for any animal/ tissue category indicates that field contamination originating from metal-enriched dust near the DMTS road generally was not problematic for cadmium, lead, or zinc.

Although aluminum concentrations did not seem to be greatly elevated in blood or livers of animals captured near the DMTS road, the reporting limits were increased above the instrument detection capability because aluminum was detected in the method blanks. In addition, one bird liver sample apparently was contaminated with aluminum (table 2), presumably during field processing. Low bioavailability of aluminum and barium (U.S. Environmental Protection Agency, 2003; 2005) from road dusts is assumed to be the reason why concentrations of these two elements did not appear to be greatly elevated in tissues of voles captured near the DMTS road; however, specialized ultra-trace field and laboratory techniques might be needed to determine unequivocally if aluminum is appreciably bioavailable to animals inhabiting this area. In principle, blood sampling using a separate needle for each sample should be less prone to surface contamination than sampling of a tissue that requires dissection of the specimen, especially if sectioning of the organ also must be performed to produce subsamples for separate assays. This seemed to be true for samples obtained in this study, as judged by the greater consistency among measured aluminum concentrations in blood as compared to liver samples (table 2), in spite of the problems of measurable aluminum in laboratory blanks.

\section{Histology and Blood Flow Cytometry}

There were no lesions in bird or vole tissues that could be associated with metal poisoning, nor was there any DNA damage apparent from flow cytometry analysis as indicated by analysis of HPCV, which is a measure of the variability of DNA content within a cell. The HPCV increases with greater intercellular DNA variability, and increased variability may be indicative of greater incidence of chromosomal damage. In these samples, variation among DNA HPCV values was not unusual, and there was no significant difference between samples obtained from DMTS road sites and those from the reference location; however, statistical comparisons of these data and any subsequent conclusions are greatly limited by the small sample sizes because genetic DNA damage caused by contaminant exposure typically is manifested only in a small percentage of individuals.

The only observed lesion potentially associated with a toxicant was multifocal mineralization of tubules in one red-backed vole from Aufeis Creek. This lesion resembles that seen in rodents exposed to vitamin D3 rodenticides, a scenario that seems unlikely at these sampling locations. Otherwise, a few general trends were noted from histological examinations. All the male birds were producing sperm and there was evidence of folliculogenesis on the ovaries of all female birds. Two of the male voles from the reference site were not producing sperm (mammals 3-5 and 3-6, table 1), but they also were among the smallest voles and probably were immature. All female voles had developing follicles or one or more corpus lutia indicating they were reproductively active when collected.

The parasite sarcocystis was detected in five birds, but such parasites are expected in wild animals. Sarcocystis is a nonfatal, usually asymptomatic infection that is caused by a parasitic protozoan. Various species of this parasite affect mammals and birds, with the most commonly reported species in North America being Sarcocystis rileyi. This parasite was associated with a myositis (inflammation of muscle) in only one bird, and otherwise would have been considered an incidental finding. In fact, four of the five birds with sarcocystis parasites were from the reference location. Leucocytozoon (a blood parasite) also was more common in the birds from Situkuyok River location, as it was present in only one other bird (from Aufeis Creek). It must be noted, however, that histological examination of tissues is not particularly sensitive for detecting blood parasites.

Heavy bacterial colonization was observed in the nonglandular parts of the stomach of three voles, all of which were from the reference location. If the nonglandular parts of more animal stomachs had been available for examination, these findings might have been more meaningful. Because the entire stomach was collected and archived, examination of additional sections from the remaining tissue specimens could be performed to provide supplemental information.

\section{Comparison of Lead Concentrations to Other Studies}

Although lead was clearly elevated in animals captured near the DMTS road, vole and small bird liver and blood concentrations generally were less than concentrations at which biological effects were clearly evident in other studies. For example, rodents, including mice and gophers, captured near metal smelters that displayed acute histopathological effects from lead toxicosis had mean lead liver concentrations of between 5 and $15 \mu \mathrm{g} / \mathrm{g}$ dry weight (Stansley and Roscoe, 1996; Damek-Poprawa and Sawicka-Kapusta, 2003; Reynolds and others, 2006). In the gophers, a blood lead concentration greater than about $1.0 \mu \mathrm{g} / \mathrm{g}$ dry weight was associated with suppressed ALAD enzyme activity (Reynolds and others, 2006). Suppression of ALAD activity is perhaps the most sensitive biochemical indicator of lead exposure, but mild suppression usually is not associated with serious biological effects (Dieter, 1979). In comparison, voles obtained from near the DMTS road in CAKR had mean lead concentrations of about $1.2 \mu \mathrm{g} / \mathrm{g}$ dry weight in liver, and about 0.6 $\mu \mathrm{g} / \mathrm{g}$ dry weight in blood. Thus, liver lead concentrations of voles near the DMTS road in CAKR were about three to five times less than liver concentrations associated with histopathological effects in mice and gophers, but their blood lead 
concentrations only were slightly less than the concentration reported to be associated with an onset of suppressed ALAD enzyme activity in gophers.

Acute metal toxicosis has seldom been documented in voles (Ma, 1996), and some researchers suggest that they are not optimal sentinel organisms for assessing metals contamination in soils, mostly because they primarily are herbivorous (Talmage and Walton, 1991). Monitoring carnivorous burrowing animals such as shrews has been recommended because they typically consume earthworms and soil particles; consequently, their metal ingestion rates are expected to be high. Nevertheless, voles continue to be frequently monitored in terrestrial risk assessments because they are abundant, widespread, have small home ranges, and sometimes constitute a large prey fraction for some top predators. In addition, they are more easily captured than shrews, and because they are considerably larger, multiple assays are more easily performed from their organs. Finally, just because a particular species accumulates greater metal concentrations does not mean that that species is at greater risk from metal exposure, because greater deposition of the metal into organs like the kidney or liver by that species could reflect a greater physiological ability to cope with the contaminant (Wijnoven and others, 2007; Shore and Rattner, 2001). In the arctic tundra, the importance of soil exposure and accordingly, the relative merits of monitoring voles as opposed to other ground-dwelling mammals for evaluating ecological risks, might be greater as compared with more temperate regions. In CAKR, the active layer of soil above the permafrost can vary from only a few centimeters to as much as one meter (depending on season and location), and in most areas it underlies a thick mat consisting of decaying peat below living moss. The extent that metal-enriched airborne dusts migrate downward into the underlying soil in CAKR is unclear. Consequently, the overlying vegetation might be a more significant source of metals exposure to voles and other herbivorous animals in this arctic tundra habitat as compared to similar studies conducted in other regions.

According to Pain (1996), Franson (1996), and Friend and Franson (1999), biological functions can be impaired and external signs of poisoning may be observed in birds when blood lead concentrations exceed about $0.5 \mu \mathrm{g} / \mathrm{mL}$ (about $3 \mu \mathrm{g} / \mathrm{g}$ dry weight), or when liver lead concentrations exceed about $20 \mu \mathrm{g} / \mathrm{g}$ dry weight, concentrations that might be classified as thresholds for serious biological effects. The U.S. Fish and Wildlife considers waterfowl with blood lead concentrations greater than $0.2 \mu \mathrm{g} / \mathrm{mL}$ (about $1.3 \mu \mathrm{g} / \mathrm{g}$ dry weight) to be above "background" (U.S. Fish and Wildlife Service, 1986). In comparison, the mean lead concentration for all 12 birds from the DMTS road sites in CAKR was $0.41 \mu \mathrm{g} / \mathrm{g}$ dry weight in blood and $2.1 \mu \mathrm{g} / \mathrm{g}$ dry weight in liver (table 2 ). The greatest lead concentration measured among these birds was in a savannah sparrow captured about $50 \mathrm{~m}$ from the DMTS road at New Heart Creek $(0.93 \mu \mathrm{g} / \mathrm{g}$ dry weight in blood; $6.2 \mu \mathrm{g} / \mathrm{g}$ dry weight in liver) - concentrations that were about 3 times less than the thresholds for serious effects. Beyer and others (2004) investigated concentrations of metals from the Tri-state lead-zinc mining district in Oklahoma, Kansas, and Missouri, and reported mean dry weight liver lead concentrations for passerine birds of $1.2 \mu \mathrm{g} / \mathrm{g}$ in mourning doves (Zenaida macroura), $4.2 \mu \mathrm{g} / \mathrm{g}$ in bank swallows (Riparia riparia), $4.7 \mu \mathrm{g} / \mathrm{g}$ in northern cardinals (Cardinalis cardinalis) and $9.3 \mu \mathrm{g} / \mathrm{g}$ in American robins (Turdus migratorius). Except for the doves, means in these other passerine birds were 1.6 to 3.5 times greater than that measured for the sparrow species captured from near the DMTS road, which was about $2.6 \mu \mathrm{g} / \mathrm{g}$ dry weight. Song sparrows (Melospiza melodia) from the Coeur D' Alene River Basin, a region contaminated with lead and zinc, had a mean liver lead concentration of about $6.7 \mu \mathrm{g} / \mathrm{g}$ dry weight (Johnson and others, 1999) or about 2.5 times greater than that of sparrows near the DMTS road. Custer and others (2002) reported 50 percent or greater reduction in ALAD activity in 25 percent of tree swallows nesting at a location where stream sediments contained increased concentrations primarily of lead, and the geometric mean lead liver concentration of those swallows was only $0.54 \mu \mathrm{g} / \mathrm{g}$ dry weight (the range was not reported), which was less than the geometric mean of $1.47 \mu \mathrm{g} / \mathrm{g}$ dry weight for all small birds captured from near the DMTS road (2.08 arithmetic mean; table 2). Thus, unless sparrows are more tolerant of lead than swallows, or the ALAD response of the swallows studied by Custer also was affected by exposure from other metals, these data indicate that subtle biochemical effects such as inhibition of ALAD enzyme activity might be possible for some of the birds nesting nearest the DMTS road. As indicated previously, acute effects usually are not observed when inhibition of ALAD activity is minor; however, in laboratory studies of birds exposed to lead, 80 percent inhibition of ALAD activity was associated with serious physiological effects (Beyer and others, 1988).

Friend and Franson (1999) noted that the amount of lead residues in lead-poisoned birds can vary considerably depending on species and route of exposure, and that assessments of biological effects caused by lead exposure in small birds were uncommon. Although concentrations of lead clearly were elevated in CAKR birds nesting near the DMTS road, serious biological effects would not be predicted based on comparison to published guidelines or to other studies. Concentrations of cadmium, barium, and zinc also were generally less in birds from CAKR than in birds from other mining sites that clearly exhibited biological effects, and none of these metals were markedly greater in birds captured near the DMTS road as compared to the reference location. Nevertheless, additional exposure assessments (particularly for lead) are recommended because of uncertainties associated with the present study, and because biological effects thresholds might be approached if exposure levels were to increase. For example, lead tissue concentrations of migratory birds might increase by late summer as a result of longer dietary exposures as compared to birds collected in late June for this study. In addition, results from some field studies have indicated that organisms were more sensitive to metal exposure than would be predicted from laboratory tests (Shore and Rattner, 2001). Considering 
how low lead concentrations were in animals from the CAKR reference location compared to those from reference locations of other studies, it is conceivable that animals of this isolated region of Alaska could be more sensitive to metals exposure than what might be expected based on data from other reports.

\section{Summary and Conclusions}

In this investigation, voles and small migratory groundnesting birds were collected from two locations near the DMTS haul road in CAKR, and one reference location in southern CAKR, to assess metals exposure and sub-lethal biological effects in these potentially at-risk animals. Aluminum, barium, cadmium, lead, and zinc specifically were targeted for this investigation based on information from an ecological risk assessment conducted between 2001 and 2004. Dust originating from road aggregate material was the presumed primary source of aluminum and barium, whereas fugitive dusts from transported lead and zinc concentrates were the presumed primary source of cadmium, lead, and zinc.

Compared to animals captured from the reference location, blood and liver metal concentrations of animals captured near the DMTS road were about 20 times greater for lead and about 3 times greater for cadmium. Concentrations of barium and zinc were not remarkably different among animals collected from different locations, and aluminum concentrations were below the reporting limits in all but three samples. Although vegetation near the DMTS road has been reported to contain markedly elevated zinc concentrations, the absence of significantly increased tissue zinc concentrations in tissues of animals obtained from near the DMTS road was not surprising because zinc is regulated internally by most vertebrates unless the dose is extraordinary. Low bioavailability of aluminum and barium from road dust might be the reason those two elements did not appear to be significantly elevated in tissues of animals captured near the DMTS road; however, because aluminum was detected in digestion blanks, aluminum reporting limits were greater than the concentrations measured in most samples. Specialized ultra-trace field and laboratory techniques might be needed to determine unequivocally if aluminum is appreciably bioavailable to animals inhabiting this area.

Increased lead exposure in voles and small birds inhabiting areas near the DMTS road was apparent, but serious biological effects such as lesions in animal organs were not. Accordingly, tissue concentrations of lead and other elements generally were less than tissue concentration thresholds associated with biological effects reported from other studies. However, subtle effects in some of the animals nearest the DMTS road, such as partial inhibition of ALAD enzyme activity as a result of lead exposure, cannot be ruled out. Furthermore, results from some field studies indicated that organisms were more sensitive to metal exposure than would be predicted from laboratory tests. Notably, liver lead concentrations of voles and small birds from the CAKR reference location were considerably less than those previously reported for similar animals obtained from reference sites in other parts of the United States, Canada, and Europe. Results from this reconnaissance-level study indicate that voles and small birds inhabiting this area are not suffering serious biological effects as a result of metals exposure; however, continued monitoring of lead and other metals is recommended because of noted uncertainties and because biological effects thresholds might be approached if exposure levels were to increase.

\section{Acknowledgments}

Gratitude is extended to Teck Cominco for their invaluable logistical support and cooperation throughout this study. Peter Neitlich (NPS) provided expert consultation and assistance with numerous aspects of the investigation. Shanti Berryman, Tim Cunningham, Galen Howell, and Bud Rice (NPS) provided helpful support for selected field activities. Amy Runck (Idaho State University) and Megan Sitzlar (Texas A\&M University) provided excellent assistance and advice with field procedures. Greg Linder (Heron Field Works) provided helpful suggestions for data analysis and interpretation. Mark Ellersieck (University of Missouri) provided guidance on statistical analysis procedures. Anonymous reviewers representing Exponent Inc. and Integral Consulting provided helpful comments on a draft version of this report.

\section{References Cited}

Alaska Department of Environmental Conservation, 2007, Contaminated Sites Program, Red Dog Mine accessed February 2008, at http://www.dec.state.ak.us/spar/csp/sites/ reddog.htm\#info

Anderson, B., 1994, Sparrows, in Wildlife Notebook Series: Alaska Department of Fish and Game, accessed March 2008, at http://www.adfg.state.ak.us/pubs/notebook/ notehome.php

Beyer, W.N., Spann, J.W., Sileo, L., and Franson, J.C., 1988, Lead poisoning in six captive avian species: Archives of Environmental Contamination and Toxicology, v. 17, p. 121-130.

Beyer, W.N., Dalgarn J., Dudding S., French J.B., Mateo, R., Miesner J., Sileo, L., and Spann, J., 2004, Zinc and lead poisoning in wild birds in the tri-state mining district (Oklahoma, Kansas, and Missouri): Archives of Environmental Contamination and Toxicology, v. 48, p. 108-117. 
Bickham, J.W., 1990, Flow cytometry as a technique to monitor the effects of environmental genotoxins on wildlife populations, in Sandhu, S.S., Lower, W.R., de Serres, F.J, Suk, W.A., and Tice, R.R., eds., In situ evaluations of biological hazards of environmental pollutants: Plenum Press, New York, p. 97-108.

Blotcky, A.J., Claassen, J.P., Roman, F.R., Rack, E.P., Badakhsh, S., 1992, Determination of aluminum by chemical and instrumental neutron activation analysis in biological standard reference material and human brain tissue: Analytical Chemistry, v. 64, p. 2,910-2,913.

Brumbaugh, W.G., and May, T.W., 2008, Elements in mud and snow in the vicinity of the DeLong Mountain Regional Transportation System Road, Red Dog Mine, and Cape Krusenstern National Monument, Alaska, 2005-06: U.S. Geological Survey Scientific Investigations Report 20085040, 30 p.

Custer, T.W., Bickham, J.W., Lyne, T.B., Lewis T., Ruedas, L.A., Custer, C.M., and Melancon, M.J., 1994, Flow cytometry for monitoring contaminant exposure in black-crowned night-herons, Archives of Environmental Contamination and Toxicology, v. 27, no 2, p. 176-179.

Custer, C.M., Custer, T.W., Archuleta, A.S., Coppock, L.C., Swartz, C.D., and Bickham, J.W., 2002, A mining-impacted stream: exposure and effects of lead and other trace elements on tree swallows (Tachycineta bicolor) nesting in the upper Arkansas River Basin, Colorado, in Hoffman D.J., Rattner, B.A., Burton Jr., G.A., and Cairns Jr., J. eds., Handbook of Ecotoxicology, 2nd ed., CRC press, Washington, D.C., p. 755-764.

Damek-Poprawa, M., and Sawicka-Kapusta, K., 2003, Damage to the liver, kidney, and testis with reference to burden of heavy metals in yellow-necked mice from areas around steelworks and zinc smelters in Poland, Toxicology, v. 186, p. $1-10$.

Dieter, M.P., 1979, Blood $\delta$-aminolevulinic acid dehydratase (ALA-D) to monitor lead contamination in canvasback ducks (Aythya valisineria), in animals as monitors of environmental pollution, National Academy Press, Washington, D.C., p. 177-191.

Exponent, 2007, DMTS Fugitive dust risk assessment volume 1-Final Report: Prepared for Teck Cominco Alaska, Incorporated, November 2007, accessed February 2008 at http://www.dec.state.ak.us/spar/csp/sites/reddog.htm\#info

Finelli, V., 1977, Lead, zinc, and $\delta$-aminolevulinic acid dehydratase, in Lee S. and B. Peirano, eds., Biochemical effects of environmental pollutants: Ann Arbor Science Publishers, Ann Arbor, Michigan, p. 351-364.
Ford, J., and Hasselbach, L., 2001, Heavy metals in mosses and soils on six transects along the Red Dog Mine Haul Road, Alaska: NPS/AR/NRTR-2001/38, accessed January 2008 at http://www.state.ak.us/dec/spar/csp/docs/reddog/ reddogrpt2.pdf

Friend, M., ed., 1987, Field guide to wildlife diseases, General field procedures and diseases of migratory birds: U.S. Fish and Wildlife Service, Resource Publication 167, 225 p.

Friend, M., and Franson, J.C., eds.,1999, Field manual of wildlife diseases: General field procedures and diseases of birds: U.S. Geological Survey, Biological Resources Division, Information and Technology Report 1999-001, Washington, D.C., 426 p.

Franson, J.C., 1996, Interpretation of tissue lead residues in birds other than waterfowl, in Beyer, W.N., Heinz, G.H., and Redmond-Norwood, A.W., eds., Environmental contaminants in wildlife: interpreting tissue concentrations: Lewis, Boca Raton Florida, p. 265-280.

Gannon, W., Sikes, R.S., and Animal Care and Use Committee of the American Society of Mammalogists, 2007, Guidelines of the American Society of Mammalogists for the Use of Wild Animals in Research: Journal of Mammalogy, v. 88, no. 3, p. 809-823.

Getz, L.L, Best, L.B., and Prather, M., 1977, Lead in urban and rural song birds: Environmental Pollution, v. 12, no. 3, p. $235-238$.

Hasselbach, L., Ver Hoef, J.M., Ford, J., Neitlich, P., Crecelius, E., Berryman, S., Wolk B., and Bohle, T., 2005, Spatial patterns of cadmium and lead deposition on and adjacent to National Park Service lands near Red Dog Mine, Alaska: Science of the Total Environment, v. 348, p. 211-238.

Johnson, G., Audet, D.J., Kern, J.W., LeCaptai, L.J., Strickland, D.M., Hoffman, D.J., and McDonald, L.L., 1999, Lead exposure in passerines inhabiting lead-contaminated floodplains in the Coeur D'Alene River Basin, Idaho, USA: Environmental Toxicology and Chemistry, v. 18, p. 1,1901,194 .

Knox, A.G., and Lowther, P.E., 2008, Common redpoll (Carduelis flammea), in Poole, A., ed., The birds of North America online: Ithaca, Cornell Laboratory of Ornithology, accessed February 2008 at http://bna.birds.cornell.edu/bna/ species/543/articles/introduction

Ma, W.-C., Denneman, W., and Faber, J., 1991, Hazardous exposure of ground-living small mammals to cadmium and lead in contaminated terrestrial ecosystem, Archives of Environmental Contamination and Toxicology v. 20, p. 266-270. 
Ma, W.-C., 1996, Lead in mammals, in Beyer, W.N., Heinz, G.H., and Redmon-Norwood, A.W. , eds., Environmental contaminants in wildlife: Interpreting tissue concentrations: Lewis Publishers/CRC Press, Boca Raton, Florida, p. 281-296.

MacDonald, S.O., and Cook, J.A., 2002, Mammal inventory of Alaska's national parks and preserves, northwest network, western arctic parklands, Annual Report 2001: accessed February, 2008 at http://www1.nature.nps.gov/ im/units/AKRO/Documents/Inventory_Reports/mamm_ nwan_01.pdf

Naugler, C.T., 1993, American tree sparrow (Spizella arborea), in Poole, A., ed., The birds of North America online: Ithaca; Cornell Laboratory of Ornithology, accessed February 2008 at http://bna.birds.cornell.edu/bna/ species/543/articles/introduction

Ornithological Council, 1999, Guidelines to the use of wild birds in research, in Gaunt, A.S., and Oring, L.W., eds., The Orninological Council, Washington, D.C., 66 p.

Osborne, T., 1994, Voles, in Wildlife Notebook SeriesAlaska Department of Fish and Game, accessed March 2008, at http://www.adfg.state.ak.us/pubs/notebook/notehome.php

Pain D.J., 1996, Lead in waterfowl, in Beyer, W.N., Heinz, G.H., and Redmond-Norwood, A.W., eds., Environmental contaminants in wildlife: interpreting tissue concentrations: Lewis, Boca Raton Florida, p. 251-264.

Reynolds, K.D., Schwarz, M.S., McFarland, C.A., Strauss, R.E., McBride, T.J., Cobb, G.P., Hooper, M.J., and McMurry, S.T., 2006, Northern pocket gophers (Thomomys talpoides) as biomonitors of environmental metal contamination: Environmental Toxicology and Chemistry v. 25, no. 2, p. $458-469$.

Saggese, M.D., Riggs, G., Tizard, I., Bratton, G., Taylor R., and Phalen, D.N., 2007, Gross and microscopic findings and investigation of the aetiopahtogenesis of mycobacteriosis in a captive population of white-winged ducks (Cairina scutulata): Avian Pathology, v. 36, p. 415-422.

SAS Institute, Inc, 2004, SAS/STAT® 9.1 user's guide, Cary, North Carolina.

Schmitt, C.J., Blazer, V.S., Dethloff, G.M., Tillitt, D.E., Gross, T.S., Bryant Jr., W.L., DeWeese, L.R., Smith, S.B., Goede, R.W., Bartish, T.M., and Kubiak, T.J., 1999, Biomonitoring of Environmental Status and Trends (BEST) Program: field procedures for assessing the exposure of fish to environmental contaminants. U.S. Geological Survey, Biological Resources Division, Columbia, (MO): Information and Technology Report USGS/BRD-1999-0007. iv + 35 pp. + appendices.
Settle, D.M, and Patterson, C.C., 1976, The reduction of orders of magnitude errors in lead analyses of biological materials and natural waters by evaluating and controlling the extent and sources of industrial lead contamination introduced during sample collection, handling and analysis in LaFleur, P. D., ed., Accuracy in trace analysis: sampling, sample handling and analysis, p. 321-351.

Shore, R.F., and Rattner, B.A., eds., 2001, Ecotoxicology of wild mammals: Wiley publishers, Chichester, New York, $752 \mathrm{p}$.

Sileo, L., Beyer, W.N, Mateo, R., 2004, Pancreatitis in wild zinc-poisoned waterfowl: Avian Pathology, v. 32, no. 6, p. $655-660$.

Stansley, W., and Roscoe, D.E., 1996, The uptake and effects of lead in small mammals and frogs at a trap and skeet range: Archives of Environmental Contamination and Toxicology, v. 30, p. 220-226.

Talmage, S.S., and Walton, B.T., 1991, Small mammals as monitors of environmental contaminants: Reviews in Environmental Contamination and Toxicology, v. 119, p. 47-145.

U.S. Environment Protection Agency, 1993, Wildlife exposure factors handbook: U.S. Environmental Protection Agency, Office of Health and Environmental Assessment and Office of Research and Development, EPA/600/R-93/187, accessed February 2008 at http://cfpub.epa.gov/ncea/cfm/wefh.cfm

U.S. Environmental Protection Agency, 1996a, Guidance on the documentation and evaluation of trace metals data collected for Clean Water Act compliance monitoring: EPA 821-B-96-002, Office of Water, Washington, D.C., 32 p.

U.S. Environmental Protection Agency, 1996b, Method 1669, Sampling ambient water for trace metals at EPA water quality criteria levels, July 1996: Office of Water, Engineering and Analysis Division, Washington, D.C., 37 p.

U.S. Environment Protection Agency, 2003, Ecological soil screening level for aluminum, Interim Final, OSWER Directive 9285.7-60: U.S. Environmental Protection Agency, Office of Solid Waste and Emergency Response, Washington, D.C., 34 p.

U.S. Environment Protection Agency, 2005, Ecological soil screening levels for barium, Interim Final, OSWER Directive 9285.7-63: U.S. Environmental Protection Agency, Office of Solid Waste and Emergency Response, Washington, D.C., 85 p.

U.S. Fish and Wildlife Service, 1986, Use of lead shot for hunting migratory birds in the United States, Final environmental impact statement: FES 86-16, U.S. Fish and Wildlife Service, Washington, D.C. 549 p. 
Wheelwright N.T., and Rising, J.D., 1993, Savannah sparrow (Passerculus sandwichensis), in Poole, A. ed., The birds of North America online: Ithaca, Cornell Laboratory of Ornithology, accessed February 2008 at http://bna.birds.cornell. edu/bna/species/045/articles/introduction
Wijnhoven, S., Leuven, R.S.E.W., van der Velde, G., Jungheim, G., Koelemij, E.I., de Vries, F.T., Eijsackers, H.J.P., and Smits, A.J.M., 2007, Heavy metal concentrations in small mammals from a diffusely polluted floodplain: Importance of species- and location-specific characteristics: Archives of Environmental Contamination and Toxicology, v. 52 , p. $603-613$. 


\section{Appendixes}


Appendix A. Quality-control results for metals in standard reference materials.

[Concentrations in micrograms per gram dry weight. Certifed concentrations are based on a complete dissolution. Recovery $=100 \%$ if measured value was in certifed or reported range, otherwise recovery calculated from upper or lower limit of certified/reported range. EK, Eastman Kodak; RM, research material; \pm , plus or minus; IAEA, International Atomic Energy Association; NC, not certified; “--”, not applicable; NIST, National Institute of Standards and Technology (USA); SRM, standard reference material]

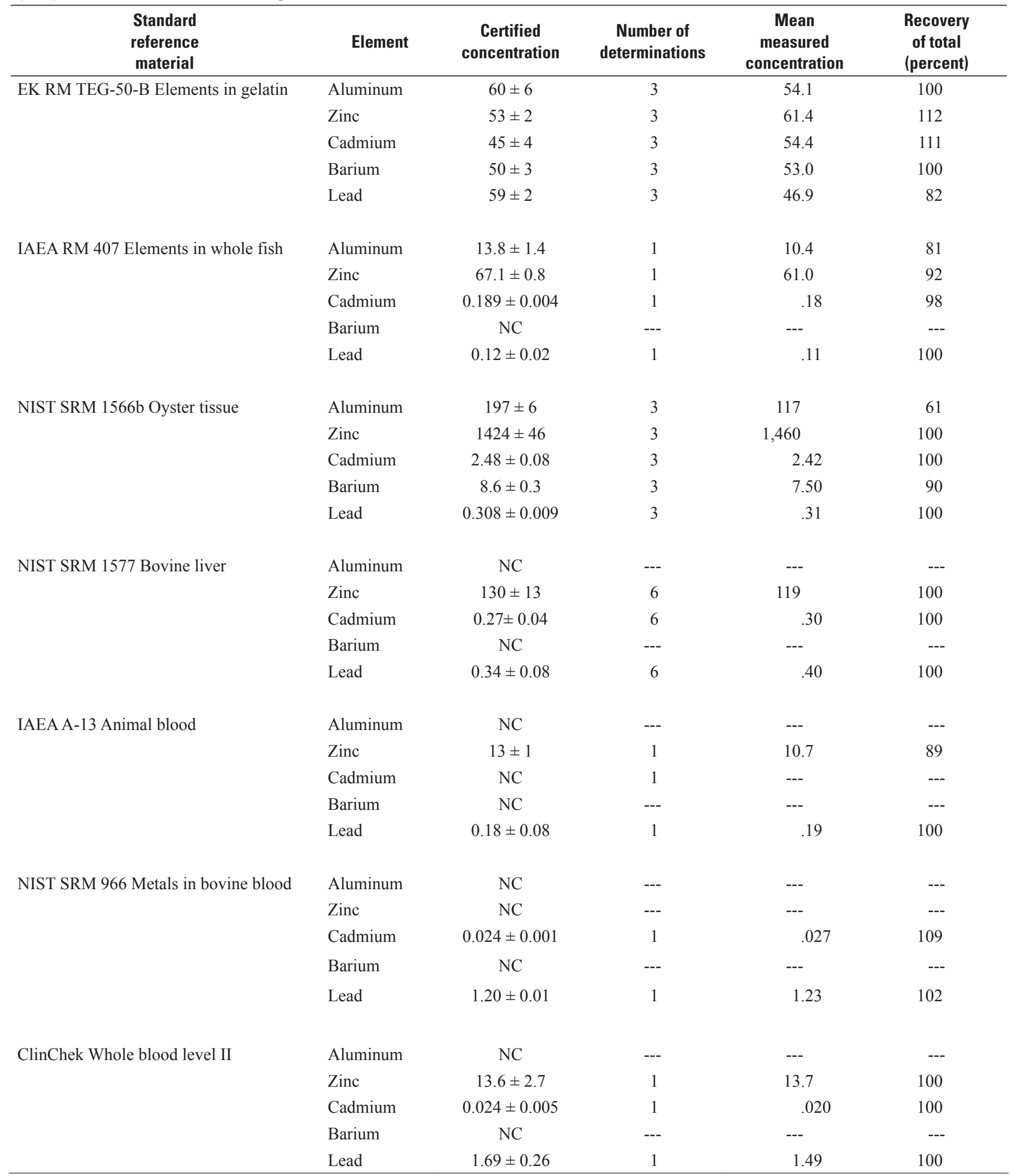


Appendix B. Quality-control results for metals in spiked samples.

[Concentrations in micrograms per gram dry weight. NIST, National Institute of Standards and Technology; IAEA, International Atomic Energy Association; $<$, less than].

\begin{tabular}{|c|c|c|c|c|c|}
\hline Spiked sample ID & Element & $\begin{array}{l}\text { Effective spike } \\
\text { concentration }\end{array}$ & $\begin{array}{l}\text { Measured unspiked } \\
\text { concentration }\end{array}$ & $\begin{array}{c}\text { Measured sample } \\
\text { and spike } \\
\text { concentration }\end{array}$ & $\begin{array}{l}\text { Spike recovery } \\
\text { (percent) }\end{array}$ \\
\hline \multirow[t]{5}{*}{ NIST 1577 low spike-1 } & Aluminum & 19.5 & 15.7 & 19.3 & ${ }^{1} 19$ \\
\hline & Zinc & 195 & 119 & 280 & 83 \\
\hline & Cadmium & 1.95 & .30 & 2.17 & 96 \\
\hline & Barium & 19.5 & .10 & 19.7 & 101 \\
\hline & Lead & 7.8 & .40 & 8.41 & 103 \\
\hline \multirow[t]{5}{*}{ NIST 1577 high spike-1 } & Aluminum & 199 & 15.7 & 200 & 92 \\
\hline & Zinc & 1,990 & 119 & 2,110 & 100 \\
\hline & Cadmium & 19.9 & .30 & 19.3 & 95 \\
\hline & Barium & 199 & .10 & 200 & 100 \\
\hline & Lead & 79.7 & .40 & 80.1 & 100 \\
\hline \multirow[t]{5}{*}{ NIST 1577 low spike-2 } & Aluminum & 20.0 & 15.7 & 27.2 & ${ }^{1} 57$ \\
\hline & Zinc & 200 & 119 & 310 & 96 \\
\hline & Cadmium & 2.0 & .30 & 2.40 & 105 \\
\hline & Barium & 20.0 & .10 & 20.7 & 103 \\
\hline & Lead & 8.0 & .40 & 8.62 & 103 \\
\hline \multirow[t]{5}{*}{ NIST 1577 high spike-2 } & Aluminum & 201 & 15.7 & 207 & 95 \\
\hline & Zinc & 2,010 & 119 & 2,186 & 103 \\
\hline & Cadmium & 20.1 & .30 & 20.3 & 100 \\
\hline & Barium & 201 & .10 & 207 & 103 \\
\hline & Lead & 80.3 & .40 & 81.5 & 101 \\
\hline \multirow[t]{5}{*}{ IAEA blood low spike } & Aluminum & 18.7 & $<4.0$ & 21.4 & 131 \\
\hline & Zinc & 93.6 & 10.7 & 95.8 & 91 \\
\hline & Cadmium & 1.87 & .002 & 1.83 & 98 \\
\hline & Barium & 18.7 & .13 & 19.2 & 102 \\
\hline & Lead & 18.7 & .19 & 19.2 & 102 \\
\hline \multirow[t]{5}{*}{ IAEA blood high spike } & Aluminum & 36.9 & $<4.0$ & 41.2 & 120 \\
\hline & Zinc & 185 & 10.7 & 188 & 96 \\
\hline & Cadmium & 3.7 & .002 & 3.70 & 100 \\
\hline & Barium & 36.9 & .13 & 37.6 & 102 \\
\hline & Lead & 36.9 & .19 & 38.2 & 103 \\
\hline \multicolumn{6}{|c|}{ Pre-digestion spike recovery summary statistics } \\
\hline & Aluminum & Zinc & Cadmium & Barium & Lead \\
\hline Mean & 86 & 95 & 99 & 102 & 102 \\
\hline Standard error & 17 & 3 & 1 & .4 & .5 \\
\hline Minimum & 19 & 83 & 95 & 100 & 100 \\
\hline Maximum & 131 & 103 & 105 & 103 & 103 \\
\hline
\end{tabular}

\footnotetext{
${ }^{'}$ Spike recovery poorly indicative of method accuracy because amount spiked was low in comparison to variability of unspiked sample measurements.
} 
Appendix C. Quality-control results for metals in replicated samples.

[Concentrations in micrograms per gram dry weight. SD, standard deviation; RPD; relative percent difference between duplicates; RSD, relative standard deviation for triplicates (in percent); NIST, National Institute of Standards and Technology; --, not applicable; EK, Eastman Kodak; CERC, Columbia Environmental Research Center; $<$, less than.]

\begin{tabular}{|c|c|c|c|c|c|c|c|}
\hline $\begin{array}{l}\text { Replicated } \\
\text { sample ID }\end{array}$ & Matrix & Element & $\begin{array}{c}\text { Number of } \\
\text { determinations }\end{array}$ & $\begin{array}{c}\text { Mean } \\
\text { measured } \\
\text { concentration }\end{array}$ & SD & RPD & RSD \\
\hline \multirow[t]{5}{*}{ NIST 1566} & Oyster & Aluminum & 3 & 117 & 1.8 & -- & 1.5 \\
\hline & & Zinc & 3 & 1,462 & 20.4 & -- & 1.4 \\
\hline & & Cadmium & 3 & 2.42 & .014 & -- & .6 \\
\hline & & Barium & 3 & 7.50 & .10 & -- & 1.4 \\
\hline & & Lead & 3 & .307 & .009 & -- & 2.9 \\
\hline \multirow[t]{5}{*}{ EK TEG 50 B } & Gelatin & Aluminum & 3 & 54.1 & 12.5 & -- & 23 \\
\hline & & Zinc & 3 & 61.4 & 1.76 & -- & 2.9 \\
\hline & & Cadmium & 3 & 54.4 & 2.10 & -- & 3.9 \\
\hline & & Barium & 3 & 53.0 & 1.56 & -- & 2.9 \\
\hline & & Lead & 3 & 46.9 & 1.12 & -- & 2.4 \\
\hline \multirow[t]{5}{*}{ NIST 1577} & Liver & Aluminum & 6 & 18.8 & 30.9 & -- & 164 \\
\hline & & Zinc & 6 & 118 & 2.86 & -- & 2.4 \\
\hline & & Cadmium & 6 & .29 & .01 & -- & 3.5 \\
\hline & & Barium & 6 & .12 & .04 & -- & 32 \\
\hline & & Lead & 6 & .41 & .01 & -- & 3.5 \\
\hline \multirow[t]{5}{*}{ CERC 37477} & Vole blood & Aluminum & 2 & $<4$ & -- & -- & -- \\
\hline & & Zinc & 2 & 17.8 & -- & 7.7 & -- \\
\hline & & Cadmium & 2 & .0014 & -- & ${ }^{1} 26.4$ & -- \\
\hline & & Barium & 2 & $<.30$ & -- & -- & -- \\
\hline & & Lead & 2 & .0504 & -- & ${ }^{1} 15.9$ & -- \\
\hline
\end{tabular}

${ }^{1}$ Large relative variation expected because sample concentration was near method detection limit. 
Publishing support provided by:

Rolla Publishing Service Center

For more information concerning this publication, contact: Director, USGS Columbia Environmental Research Center 4200 New Haven Road

Columbia, MO 65201

(573) 875-5399

Or visit the Columbia Environmental Research Center Web site at: http://www.cerc.usgs.gov 

Back cover. Top photograph, view from haul road at New Heart Creek bridge, looking due east, Cape Krusenstern National Monument, Alaska, June 24, 2006. Bottom photograph, dissection of small bird inside sample preparation tent located near New Heart Creek, Cape Krusenstern National Monument, Alaska, June 23, 2006. (Photographs taken by William Brumbaugh, U.S. Geological Survey.) 


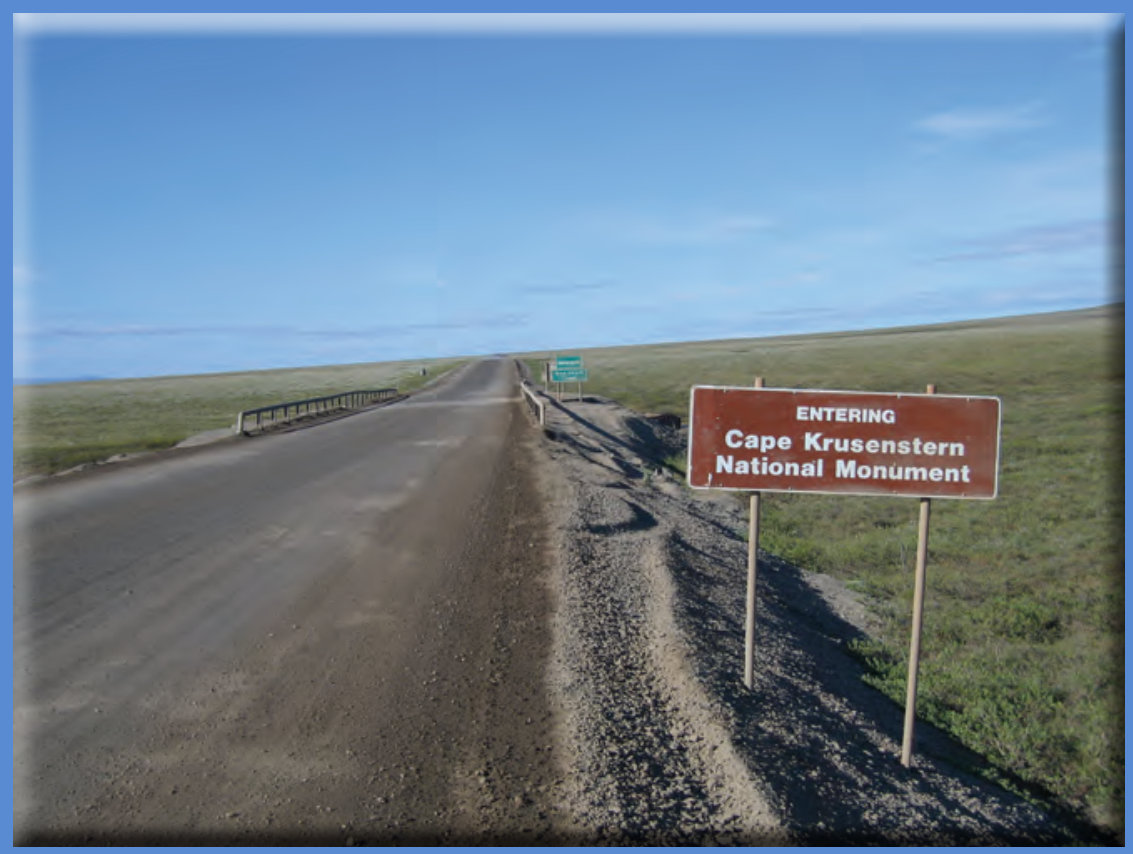

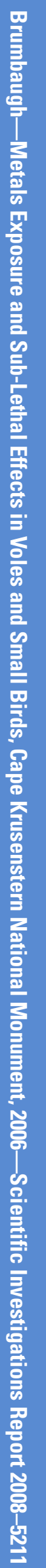

